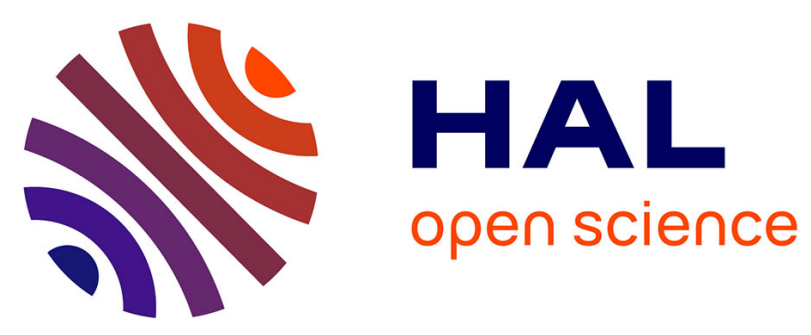

\title{
Impact of surface roughness and soil texture on mineral dust emission fluxes modeling
}

\author{
Laurent Menut, C. Perez, K. Haustein, Bertrand Bessagnet, Catherine
}

Prigent, S. Alfaro

\section{- To cite this version:}

Laurent Menut, C. Perez, K. Haustein, Bertrand Bessagnet, Catherine Prigent, et al.. Impact of surface roughness and soil texture on mineral dust emission fluxes modeling. Journal of Geophysical Research: Atmospheres, 2013, 118 (12), pp.6505-6520. 10.1002/jgrd.50313 . ineris-00963474

\section{HAL Id: ineris-00963474}

\section{https://hal-ineris.archives-ouvertes.fr/ineris-00963474}

Submitted on 22 Oct 2021

HAL is a multi-disciplinary open access archive for the deposit and dissemination of scientific research documents, whether they are published or not. The documents may come from teaching and research institutions in France or abroad, or from public or private research centers.
L'archive ouverte pluridisciplinaire HAL, est destinée au dépôt et à la diffusion de documents scientifiques de niveau recherche, publiés ou non, émanant des établissements d'enseignement et de recherche français ou étrangers, des laboratoires publics ou privés.

$$
\text { Copyright }
$$




\title{
Impact of surface roughness and soil texture on mineral dust emission fluxes modeling
}

\author{
Laurent Menut, ${ }^{1}$ Carlos Pérez, ${ }^{2,3}$ Karsten Haustein, ${ }^{4,5}$ Bertrand Bessagnet, ${ }^{6}$ \\ Catherine Prigent, ${ }^{7}$ and Stéphane Alfaro ${ }^{8}$ \\ Received 25 October 2012; revised 27 February 2013; accepted 2 March 2013; published 22 June 2013.
}

[1] Dust production models (DPM) used to estimate vertical fluxes of mineral dust aerosols over arid regions need accurate data on soil and surface properties. The Laboratoire Inter-Universitaire des Systemes Atmospheriques (LISA) data set was developed for Northern Africa, the Middle East, and East Asia. This regional data set was built through dedicated field campaigns and include, among others, the aerodynamic roughness length, the smooth roughness length of the erodible fraction of the surface, and the dry (undisturbed) soil size distribution. Recently, satellite-derived roughness length and high-resolution soil texture data sets at the global scale have emerged and provide the opportunity for the use of advanced schemes in global models. This paper analyzes the behavior of the ERS satellite-derived global roughness length and the State Soil Geographic data base-Food and Agriculture Organization of the United Nations (STATSGO-FAO) soil texture data set (based on wet techniques) using an advanced DPM in comparison to the LISA data set over Northern Africa and the Middle East. We explore the sensitivity of the drag partition scheme (a critical component of the DPM) and of the dust vertical fluxes (intensity and spatial patterns) to the roughness length and soil texture data sets. We also compare the use of the drag partition scheme to a widely used preferential source approach in global models. Idealized experiments with prescribed wind speeds show that the ERS and STATSGO-FAO data sets provide realistic spatial patterns of dust emission and friction velocity thresholds in the region. Finally, we evaluate a dust transport model for the period of March to July 2011 with observed aerosol optical depths from Aerosol Robotic Network sites. Results show that ERS and STATSGO-FAO provide realistic simulations in the region.

Citation: Menut, L., C. Pérez, K. Haustein, B. Bessagnet, C. Prigent, and S. Alfaro (2013), Impact of surface roughness and soil texture on mineral dust emission fluxes modeling, J. Geophys. Res. Atmos., 118, 6505-6520, doi:10.1002/jgrd.50313.

\footnotetext{
${ }^{1}$ Institut P.-S. Laplace, Laboratoire de Météorologie Dynamique, CNRS UMR 8539, Ecole Polytechnique, Palaiseau, France.

${ }^{2}$ NASA Goddard Institute for Space Studies, New York, New York, USA.

${ }^{3}$ Department of Applied Physics and Applied Math, Columbia University, New York, New York, USA.

${ }^{4}$ Earth Sciences Division, Barcelona Supercomputing Center, Barcelona, Spain.

${ }^{5}$ School of Geography and the Environment, University of Oxford, Oxford, UK.

${ }^{6}$ INERIS, Institut National de 1'Environnement Industriel et des Risques, Verneuil en Halatte, France.

${ }^{7}$ Laboratoire d'Etudes du Rayonnement et de la Matière en Astrophysique, CNRS UMR 8112, Observatoire de Paris, Paris, France.

${ }^{8}$ Laboratoire Inter-Universitaires des Systèmes Atmosphériques, CNRS UMR 7583, Université Parie-Est Créteil, Université Paris Diderot, Créteil, France.

Corresponding author: Laurent Menut, Laboratoire de Météorologie Dynamique, Ecole Polytechnique, Palaiseau, France.

(menut@1md.polytechnique.fr)

(C)2013. American Geophysical Union. All Rights Reserved.

2169-897X/13/10.1002/jgrd.50313
}

\section{Introduction}

[2] Dust aerosol particles are produced by wind erosion in arid and semiarid surfaces. From the local to the global scale, modeling of mineral dust remains a challenge. While dust distribution and dust effects are important at global scales, they strongly depend on dust emission, which is a threshold, sporadic and spatially heterogeneous phenomenon, locally controlled on small spatial and temporal scales. Since dust plays a key role in regional to global climate and air quality because of its effects upon radiation, ocean biogeochemistry, and human health, it is necessary to accurately represent its emission, transport, and deposition at different spatial and temporal scales.

[3] During the last years, many efforts have been devoted to the reduction of emission uncertainties. Current theoretical knowledge would allow a satisfactory calculation of the vertical dust flux in models if the required input parameters - surface, soil, and meteorological featureswere accurately determined. However, the application of complex emission schemes in global and to a lesser extent regional models is mainly hampered by the lack or the strong 
uncertainties of the required input data at the pertinent scales and the inaccuracies of the driving meteorological model mainly with respect to surface wind velocities, turbulence, and stability.

[4] In order to partly overcome these limitations, current global models [e.g., Tegen et al., 2002; Mahowald et al., 2003; Miller et al., 2006] have assumed varying degrees of simplification in the dust emission scheme as a function of the availability and accuracy of the input data, and in most cases several parameters are tuned to match quantitative dust observations that are mainly available far away from sources.

[5] Regional mineral dust models have been also developed and used for particular regions such as, for example, DREAM [Nickovic et al., 2001; Perez et al., 2006] and CHIMERE [Menut et al., 2007] in Northern Africa. Although simplifications also apply to regional models, some of them include specific surface and soil data sets developed for the most well-known source regions [e.g., Chatenet et al., 1996; Callot et al., 2000]. Numerous sensitivity experiments have been performed to better understand and quantify strengths and weaknesses of different formulations and data sets. The sensitivity to various dust production models and meteorology was quantified in Todd et al. [2008] over the Bodele region and Menut [2008], Cheng et al. [2008], and Zhao et al. [2010], among others.

[6] In dust model intercomparison exercices [Textor et al., 2006, 2007; Todd et al., 2008; Huneeus et al., 2011] surface, soil, meteorology, and dust production models (DPMs) vary from one model configuration to the other. It is therefore difficult to attribute model differences to a specific parameter or forcing, and error compensations are always possible. In an interesting effort, Darmenova et al. [2009] made an indepth comparative analysis of two different physically based schemes which were originally developed by Marticorena and Bergametti [1995] and Shao et al. [1996]. The relative importance of the input parameters was assessed, and some recommendations were provided on the selection of input parameters, including land and meteorological variables, to achieve an improved modeling of dust emission in Central and East Asia. A more recent study implemented three dust schemes in WRF-Chem and compared the vertical dust fluxes, highlighting large differences for the same meteorological conditions and surface and soil data [Kang et al., 2011]. In parallel, Wang et al. [2012] implemented and compared two emissions schemes in Community Multiscale Air quality Modeling System (CMAQ).

[7] In this paper, the sensitivity of mineral dust fluxes to surface and soil features is studied over Northern Africa.

[8] Concerning the soil, the fractions of clay, silt, and sand from global soil data sets [e.g., Zobler, 1986] are generally mapped according to the well-known textural triangle which is based on measurements using wet sedimentation techniques that may strongly overestimate the amount of loose clay particles [Laurent et al., 2008]. In this paper, we will compare this approach against an alternative approach using dry techniques [Chatenet et al., 1996].

[9] Another very important parameter is the aerodynamic roughness length, $z_{0}$, that controls the threshold wind friction velocity above which saltation starts. The estimates of roughness length used in meteorological models do not apply to the scales needed for describing the dust emission process. Only recently, new encouraging approaches based on satellites [Prigent et al., 2005; Laurent et al., 2008] were proposed for providing the information on aerodynamic roughness lengths appropriate for global and regional dust models. We test and compare the spatial distribution of emissions using a drag partition scheme with different roughness length estimates [Prigent et al., 2005; Marticorena and Bergametti, 1995].

[10] Partly due to the lack of aerodynamic roughness length data sets at a global scale, a very common approach has been the prescription of an erodibility factor that accounts for the spatial distribution of dust source intensities. Prospero et al. [2002] showed that enclosed basins containing former lake beds or riverine sediment deposits are preferential sources dominating global dust emission. Several model representations of preferential sources have been used based on topographic [Ginoux et al., 2001], hydrological [Tegen et al., 2002], or geomorphological [Zender et al., 2003] approximations. Also, surface reflectance retrieved from Moderate Resolution Imaging Spectroradiometer (MODIS) [Grini et al., 2005], the frequency of high Aerosol Index values [Westphal et al., 2009], and the UV-visible surface albedo [Morcrette et al., 2009] have been used to identify preferential sources. The results of sensitivity experiments with different preferential source formulations at a global scale [Zender et al., 2003; Cakmur et al., 2006] are rather inconclusive since they are dependent on the model and evaluation data as well as on the optimization and evaluation methods. The most popular representation of sources in dust modeling which has shown significant improvements is the topographic approach of Ginoux et al. [2001]. In this paper, we also test and analyze this approach in comparison to the use of aerodynamic roughness lengths in a drag partition scheme.

[11] The paper is structured as follows. Section 2 describes the surface and soil data sets compared in this study. Section 3 describes the Dust Production Model (DPM) used. The sensitivity studies are performed using a combination of idealized and real-world model experiments: In section 4, we quantify and discuss, under idealized meteorology, the spatial distribution of emissions in the region when using different formulations and data sets describing the soil and surface conditions in the region, and in section 5, we use a dust transport model to compare real-world simulations with different formulations against aerosol optical depth measurements in the region. A summary is given in section 6.

\section{Surface and Soil Data}

\subsection{Soil Type and Soil Texture Data}

[12] In this study, we use two different soil data sets, hereafter named LISA and STATSGO-FAO. The regional LISA-soil data set was developed by [Marticorena and Bergametti, 1995] for Northern Africa. The data are available at http://www.lisa.univ-paris $12 . \mathrm{fr} / \mathrm{mod} / \mathrm{data} /$. The STATSGO-FAO is a global data set used in meteorological modeling and which may be used for global and regional dust transport modeling, and the data are available at http:// soils.usda.gov/survey/geography/.

[13] Both provide soil texture characteristics over longitude/latitude regular grids. The native resolution of 

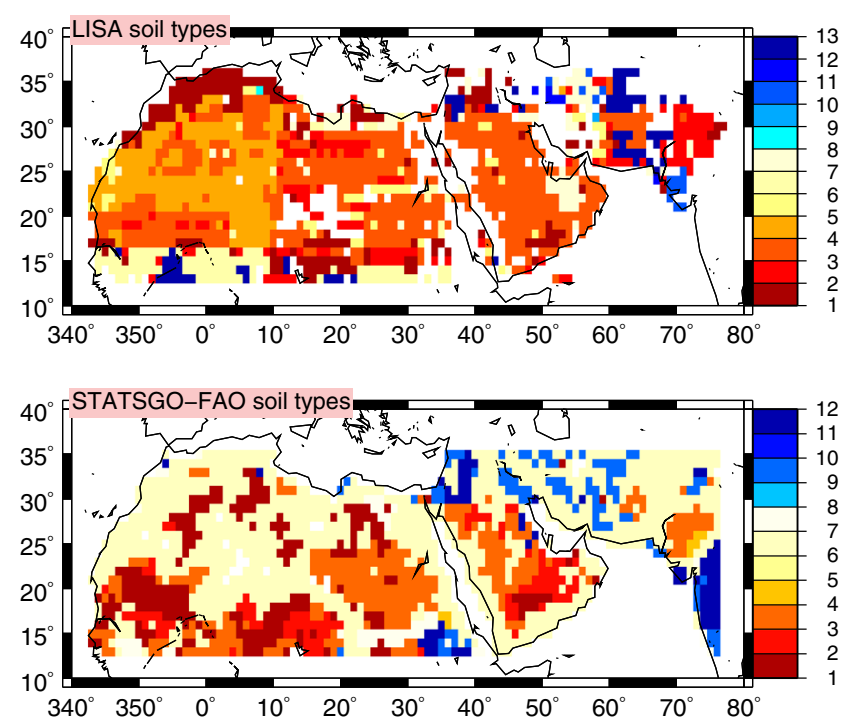

Figure 1. The LISA and STATSGO-FAO soil types data reggridded to $1^{\circ} \times 1^{\circ}$ resolution. The values correspond to the surface types explained in Table 1. For each cell, only the most important relative surface is displayed (on a total of five possible surface types in a cell).

the data sets are different: $1^{\circ} \times 1^{\circ}$ for LISA soil and $0.0083^{\circ} \times 0.0083^{\circ}$ for STATSGO-FAO. In order to have homogeneous data sets, the STATSGO-FAO data are regridded into a regular $1^{\circ} \times 1^{\circ}$ grid, retaining the dominant feature as presented in Figure 1.

[14] The soil types in the two data sets are listed in Table 1 together with their relative percentage of clay, silt, salt, and sand (coarse and fine-medium). Note that STATSGO-FAO does not contain salts and that fine-medium sand and coarse sand are distinguished according to criteria detailed in Tegen et al. [2002]. With this approach, clay loams are considered as highly unlikely to contain coarse sand, and sandy clay loam can contain both coarse and medium fine sand. The textural triangle is based on measurements performed by wet sedimentation techniques which break the soil aggregates, leading to high amounts of loose clay particles that generally form aggregates of larger size and that may not be encountered in natural soils. Following Tegen et al. [2002], clay is in the form of aggregate in loamy sands, and it is reassigned to the silt fraction. In the case of LISA, only the clayey soil type contains clay particles.

[15] Each soil population can be described in terms of a mean mass median diameter, $D_{p}(\mu \mathrm{m})$, and an associated standard deviation $\sigma$ (Table 2). An issue is that the two data sets do not use the same values. For the LISA data set, the characteristics of the soil types are from Chatenet et al. [1996], and for the STATSGO-FAO from Tegen et al. [2002]. In this study, for the sake of comparison, we use the same size-distribution characteristics for each population in the soil as displayed in the third column of Table 2.

[16] Each LISA-soil grid cell contains the proportion of the five most dominant soil types. For the highly resolved STATSGO-FAO data set, we follow the same approach by counting the relative proportion of the five most dominant soil types in $1^{\circ} \times 1^{\circ}$ cells.
Table 1. Characteristics of Each Model Soil Type ${ }^{\mathrm{a}}$

\begin{tabular}{|c|c|c|c|c|c|c|}
\hline \multirow[b]{2}{*}{ Number } & \multicolumn{5}{|c|}{$\%$} & \multirow[b]{2}{*}{ Soil Type } \\
\hline & $\mathrm{CS}$ & FMS & Silt & Clay & Salt & \\
\hline \multicolumn{7}{|c|}{ LISA data soil types } \\
\hline 1 & 0 & 62.5 & 37.5 & 0 & 0 & silty fine sand \\
\hline 2 & 80 & 20 & 0 & 0 & 0 & medium sand \\
\hline 3 & 100 & 0 & 0 & 0 & 0 & coarse sand \\
\hline 4 & 90 & 10 & 0 & 0 & 0 & coarse medium sand \\
\hline 5 & 0 & 100 & 0 & 0 & 0 & fine sand \\
\hline 6 & 31.25 & 31.25 & 37.5 & 0 & 0 & silty medium sand \\
\hline 7 & 0 & 0 & 20 & 0 & 80 & salty medium sand \\
\hline 8 & 0 & 0 & 8 & 0 & 92 & salty silt fort \\
\hline 9 & 0 & 0 & 0 & 100 & 0 & clayey soil \\
\hline 10 & 0 & 0 & 50 & 0 & 50 & salt waste \\
\hline 11 & 0 & 0 & 100 & 0 & 0 & agricultural soil \\
\hline 12 & 0 & 50 & 10 & 0 & 40 & salty fine sand \\
\hline 13 & 60 & 0 & 40 & 0 & 0 & silty coarse sand \\
\hline \multicolumn{7}{|c|}{ STATSGO-FAO data soil types } \\
\hline 1 & 46 & 46 & 5 & 3 & 0 & sand \\
\hline 2 & 41 & 41 & 18 & 0 & 0 & loamy sand \\
\hline 3 & 29 & 29 & 32 & 10 & 0 & sandy loam \\
\hline 4 & 0 & 17 & 70 & 13 & 0 & silt loam \\
\hline 5 & 0 & 10 & 85 & 5 & 0 & silt \\
\hline 6 & 0 & 43 & 39 & 18 & 0 & loam \\
\hline 7 & 29 & 29 & 15 & 27 & 0 & sandy clay loam \\
\hline 8 & 0 & 10 & 56 & 34 & 0 & silty clay loam \\
\hline 9 & 0 & 32 & 34 & 34 & 0 & clay loam \\
\hline 10 & 0 & 52 & 6 & 42 & 0 & sandy clay \\
\hline 11 & 0 & 6 & 47 & 47 & 0 & silty clay \\
\hline 12 & 0 & 22 & 20 & 58 & 0 & clay \\
\hline
\end{tabular}

${ }^{\mathrm{a}} \mathrm{CS}=$ coarse sand; FMS $=$ fine-medium sand.

\subsection{Land Use Data}

[17] Land use data describe the surface occupation (wood, mountains, lakes, etc.) and is typically used to prescribe some properties in meteorological models, such as the roughness length, $z_{0}$. For each land use type, a $z_{0}$ is typically prescribed. As described in the next section, roughness lengths based on land use types are not appropriate for use in dust emission parameterizations.

[18] For mineral dust emission calculations, the land use is typically used to provide a desert mask specifying what surface is potentially erodible. The LISA data set already contains this information as the percentage of erodibility in each grid cell. Global or regional models typically consider arid and semiarid categories from a land use database to identify potential dust source areas. Here, to complement the STATSGO-FAO soil data set, we use the U.S. Geological Survey (USGS) land use data set with a high horizontal resolution $\left(0.0083^{\circ} \times 0.0083^{\circ}\right)$. As in the case of the STATSGO-FAO data set, we calculated the relative surface

Table 2. Mean Characteristics of the Soil Textures ${ }^{\mathrm{a}}$

\begin{tabular}{|c|c|c|c|c|c|c|}
\hline \multirow[b]{2}{*}{ Soil } & \multicolumn{2}{|c|}{ C1996 } & \multicolumn{2}{|c|}{ T2002 } & \multicolumn{2}{|c|}{ TS } \\
\hline & $\mathrm{D}_{p}$ & $\sigma$ & $\mathrm{D}_{p}$ & $\sigma$ & $\mathrm{D}_{p}$ & $\sigma$ \\
\hline Coarse sand & 690 & 1.6 & 710 & 2 & 690 & 1.6 \\
\hline Fine-medium sand & 210 & 1.6 & 160 & 2 & 210 & 1.6 \\
\hline Silt & 125 & 1.8 & 15 & 2 & 125 & 1.8 \\
\hline Clay & - & - & 2 & 2 & 2 & 2 \\
\hline Salts & 520 & 1.5 & - & 2 & 520 & 1.5 \\
\hline
\end{tabular}

${ }^{a}$ Used for the dust flux calculations with the mean mass median diameter $\mathrm{D}_{p}$ in micrometer. C1996 refers to Chatenet et al. [1996], T2002 to Tegen et al. [2002], and TS to this study. 

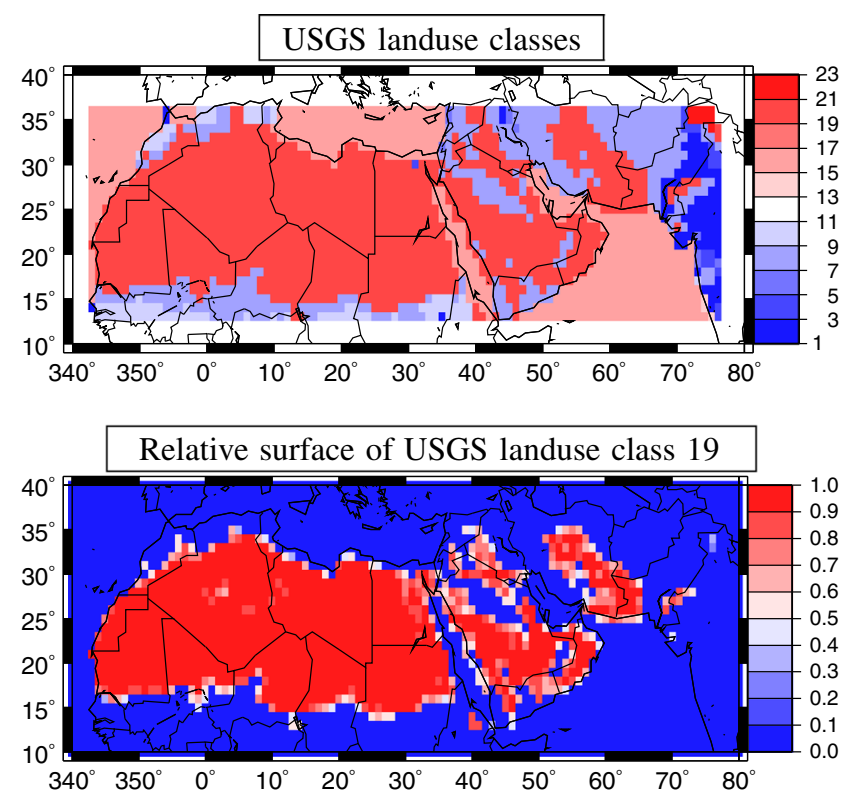

Figure 2. (top) The USGS land use classes (from 1 to 23) over the domain: (1) urban and built-up land, (2) dryland cropland and pasture, (3) irrigated cropland and pasture, (4) mixed dryland/irrigated cropland and pasture, (5) cropland/grassland mosaic, (6) cropland/woodland mosaic, (7) grassland, (8) shrubland, (9) mixed shrubland/grassland, (10) savanna, (11) deciduous broadleaf forest, (12) deciduous needleleaf forest, (13) evergreen broadleaf forest, (14) evergreen needleleaf forest, (15) mixed forest, (16) water bodies, (17) herbaceous wetland, (18) wooded wetland, (19) barren or sparsely vegetated, (20) herbaceous tundra, (21) wooded tundra, (22) mixed tundra, and (23) bare ground tundra. (bottom) The relative percentage of USGS class 19 surface (for barren soils). This class is used as a desert mask for the dust fluxes calculation when using the USGS data.

of the five most important land use types in $1^{\circ} \times 1^{\circ}$ cells. The erodible land use types considered were scrublands (8) and barren soil (19). This may appear as a limiting choice, but this corresponds to the most important land use classes able to produce dust in Northern Africa. This constitutes the desert mask as presented in Figure 2.

\subsection{Roughness Length}

[19] Models use $z_{0}$ to calculate surface boundary conditions for wind by representing the effect on turbulent transport of surface elements ranging from vegetation and small-scale obstacles to sub-grid orography. Depending on the spatial scale, the surface roughness varies widely. In meteorological modeling, $z_{0}$ is mainly used to estimate the friction velocity, a turbulent parameter designed to estimate the wind speed near the surface. $z_{0}$ in a grid cell will be defined such that the modeled wind is realistic compared to measurements. In this sense, $z_{0}$ in a model has no "physical" and "realistic" meaning: this is a parameter defined to integrate correctly the vertical wind.

[20] In dust modeling, the roughness length may be used to estimate the threshold friction velocity. In meteorological and dust models, three roughness lengths at different scales may be distinguished as illustrated in Figure 3 .

[21] 1. At the synoptic scale: This "aerodynamic" roughness length is used mainly for the atmospheric part of the model to calculate the friction velocity to take into account the role of subgrid orography, forests, or urbanization when slowing the mean wind fields at large scale. Values are often look-up tables or just constant over desert surfaces. The values generally range from $1 \mathrm{~cm}$ to $1 \mathrm{~m}$. This is the case of the USGS values presented in Figure 4. This data set is not appropriate for the calculation of the threshold friction velocity in dust models since it does not represent the roughness at the scale needed for the emission process over arid areas. This data set is used in WRF model (http://wrf-model. org/index.php) and is available with the WRF distribution.

[22] 2. At the mesoscale: The roughness length accounts for small vegetation and obstacles. Values are generally lower than the "synoptic" roughness length and range from millimeter to centimeter. This is the case of the LISA data set: $z_{0}$ is provided after the compilation by Chatenet et al. [1996] and Callot et al. [2000]. The values are representative of local effects and constitute a more realistic $z_{0}$ data set for this study. Another available data set, hereafter called ERS, is derived from ERS-1 satellite measurements (with a horizontal resolution of $0.25^{\circ} \times 0.25^{\circ}$ ) [Prigent et al., 2005]. The retrieval approach differs from the in situ based approach used for the LISA data set and constitutes an interesting alternative for dust emission calculations at a global scale.

[23] 3. At the local scale: The smooth roughness length, $z_{0 s}$, accounts for mobile erodible sand particles over arid and semiarid areas. This length is generally tabulated or calculated using the mean mass median diameter of the erodible particles, $D_{p}$, as $z_{0 s}=D_{p} / 30$, [Marticorena et al., 1997].

[24] In reality, two different types of wind profiles are known for fully developed turbulent flow: the wind profile over aerodynamically rough and over aerodynamically smooth surfaces. In the first case, $z_{0}$ is a function of the roughness elements. At the same time, over arid regions, roughness increases apparently due to the suspension of an increasing number of particles. At low wind speeds, arid surfaces (also water surfaces) become aerodynamically smooth, and $z_{0 s}$ is embedded in the viscous sublayer and scales with the kinematic viscosity.

[25] In this study, the roughness length is prescribed to estimate dust emissions, i.e., we do not take into account viscous sublayer effects or the apparent increase of roughness due to saltating particles. We note that in some advanced atmospheric models widely used in the community (e.g., NCEP/Eta, NMM5, WRF/ARW, WRF/NMM), viscous sublayers are explicitly taken into account, and the distinction between aerodynamically smooth and rough surfaces is thus available [Janjic, 1994; Zilitinkevich et al., 2008]. With respect to dust emissions, to our knowledge, only the study of Nickovic et al. [2001] intends to include viscous sublayer effects in a dust emission scheme.

[26] Here, the roughness effect on dust emissions is parameterized through a drag partition scheme which expresses the efficiency with which drag is partitioned between the roughness elements characterized by the aerodynamic roughness length $\left(z_{0}\right)$ and the erodible surface characterized by a smooth roughness length $\left(\mathrm{z}_{0 s}\right)$. The different values of $z_{0}(\mathrm{~cm})$ used in this study are presented in 


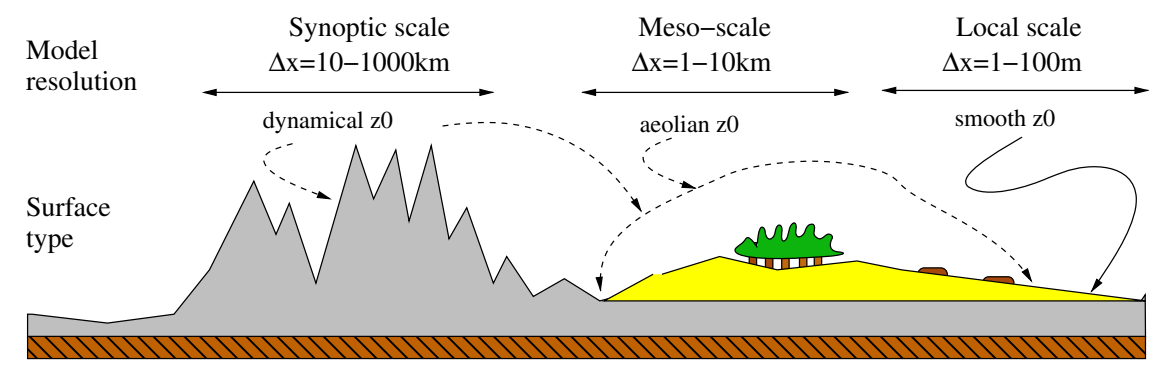

Figure 3. The roughness length definitions as a function of its use in local to global meteorological and dust transport models.

Figure 4. The LISA values show an important spatial variability and a large range of values (from $z_{0}=10^{-4}$ to $10 \mathrm{~cm}$ ). The ERS values are spatially variable and close to the LISA values. The USGS values are homogeneous over the whole domain and are related to the most present land use, barren soil. This leads to very high values (1 order of magnitude higher than those of LISA and ERS): in this case, a drag partition scheme is not usable [MacKinnon et al., 2004], and the USGS data set will only be used for the calculation of the friction velocity.

\section{Dust Production Model Design}

[27] The dust emission fluxes are calculated using the parameterization of Marticorena and Bergametti [1995] (hereafter denoted MB95) for saltation and the DPM proposed by Alfaro and Gomes [2001] (hereafter denoted AG01) for sandblasting. Before calculating the fluxes, the estimation of the friction velocity is required. All steps involved in the calculation are presented in this section.

\subsection{The Friction Velocity}

[28] The friction velocity, $u_{*}$, is estimated under neutral conditions, as follows:

$$
u^{*}=|U| \frac{k}{\ln \left(z / z_{0}\right)}
$$

with $|U|$ the $10 \mathrm{~m}$ mean wind speed, $k=0.41$, the Karman constant, $z$ the height above ground level where the wind speed is estimated by the meteorological model, in this case $z=10 \mathrm{~m}$, and $z_{0}$ the roughness length. This roughness length is a key point for this study. The same calculation is used to estimate dust fluxes in the idealized case and for the real case.

\subsection{The Threshold Friction Velocities and the Drag Efficiency}

[29] The saltation flux $F_{h}$ is nonzero only if $u_{*}>u_{*}^{T}\left(D_{p}\right)$ for a given soil particle diameter $D_{p} . u_{*}^{T}$ is the threshold friction velocity depending on $D_{p}$, the soil particle diameter, $z_{0}$, the "aeolian" roughness length, and $z_{0 s}$, the "smooth" roughness length.

[30] The "smooth" threshold friction velocity $u_{*}^{T S}$ is estimated following Shao and $L u$ [2000]:

$$
u_{*}^{T S}\left(D_{p}\right)=\sqrt{a_{n}\left(\frac{\rho_{p} g D_{p}}{\rho_{\text {air }}}+\frac{\gamma}{\rho_{\text {air }} D_{p}}\right)}
$$

with the constant parameters $a_{n}=0.0123$ and $\gamma=$ $300 \mathrm{~kg} \mathrm{~m}^{-2}$. The particle density, $\rho_{p}=2.6510^{3} \mathrm{~kg} \mathrm{~m}^{-3}$ is chosen to be representative of quartz grains.

[31] The threshold friction velocity, $u_{*}^{T}$, is expressed as follows:

$$
u_{*}^{T}\left(D_{p}\right)=\frac{u_{*}^{T s}\left(D_{p}\right) \times q}{f_{\mathrm{eff}}\left(z_{0}, z_{0 s}\right)}
$$

with $q$ a soil moisture correction. For the idealized study in section 4 , this correction is set to $q=1$.
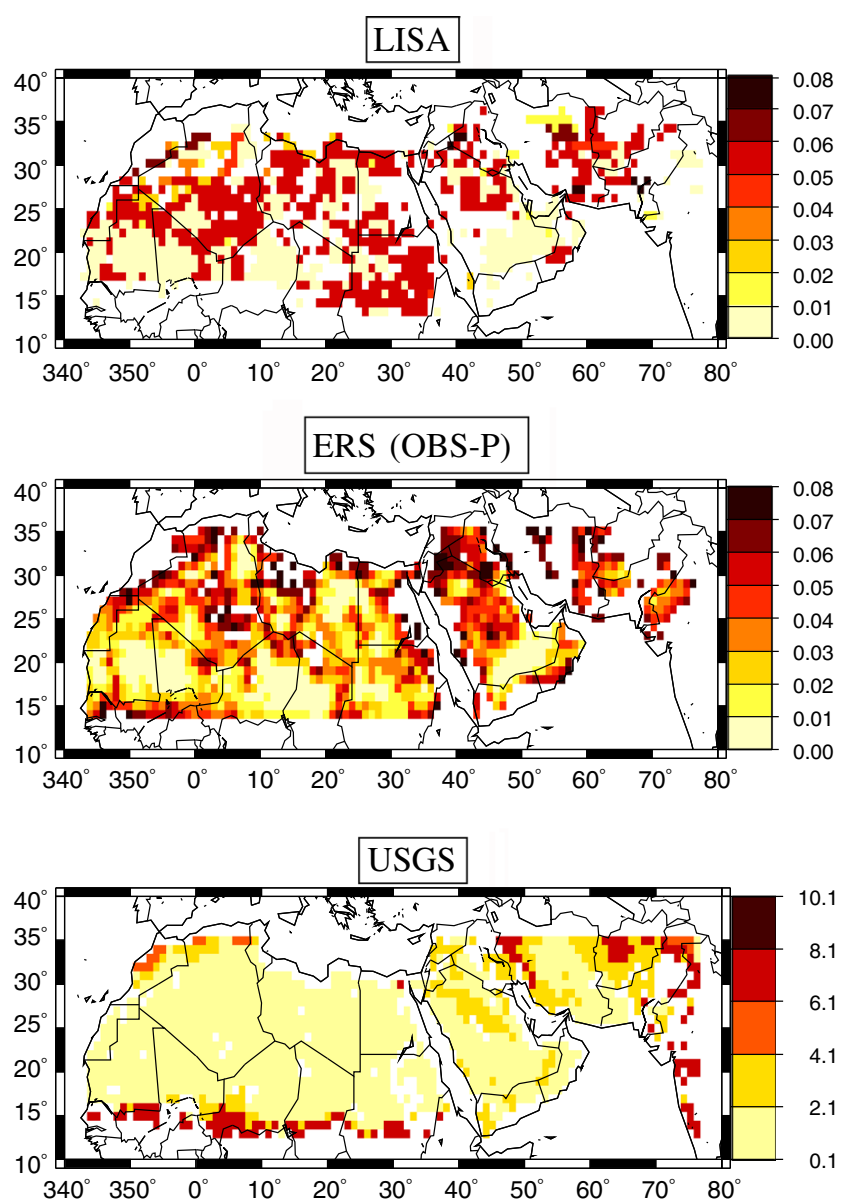

Figure 4. Comparison of the aerodynamic roughness lengths, $z_{0}(\mathrm{~cm})$, provided with the three surface data sets and for the most important relative surface fraction for each cell. Horizontal resolution is $1^{\circ} \times 1^{\circ}$. The color scale is the same as in Prigent et al. [2005] for LISA and ERS but different for USGS, the values being 1 order of magnitude higher. 


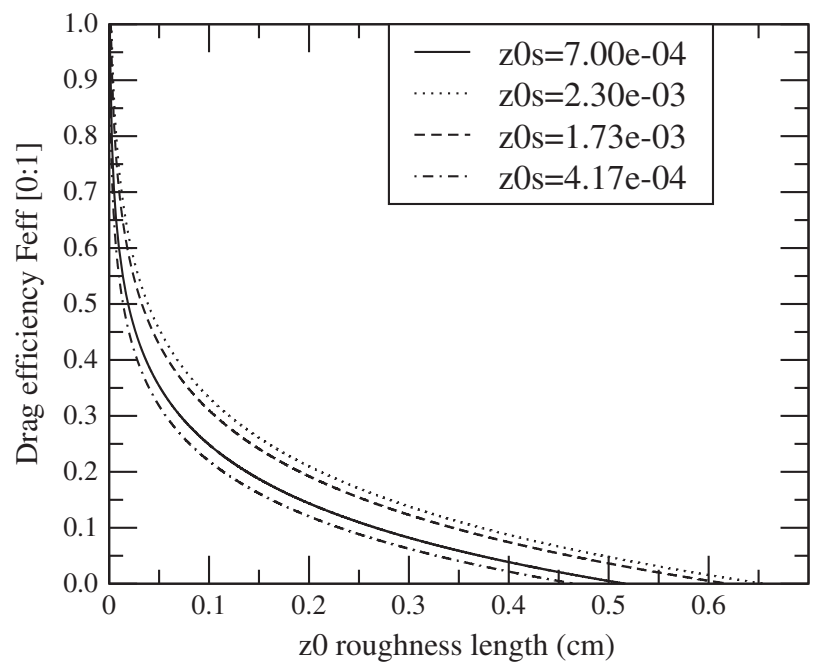

Figure 5. The drag efficiency calculated for a wide range of roughness length ad for specific values of the smooth roughness length, depending on the mean mass median diameter of the particles.

[32] $f_{\text {eff }}$ represents the drag efficiency, i.e., a function depending on $z_{0}$, the "aeolian" roughness length and $z_{0 s}$, the "smooth" roughness length which is expressed as follows [Marticorena et al., 1997]:

$$
f_{\text {eff }}=\left[1-\left(\frac{\ln \left(z_{0} / z_{0 s}\right)}{\ln \left(0.35\left[\left(0.1 / z_{0 s}\right)^{0.8}\right]\right)}\right)\right]
$$

[33] This function takes into account the non-erodible elements dissipating a part of the wind momentum that will not be available for saltation.

[34] The evolution of this parameter as a function of the roughness length values is displayed in Figure 5. The drag efficiency is limited to have values between 0 and 1. For $f_{\text {eff }}=1$, the threshold friction velocity $u_{*}^{T}$ is equal to the smooth threshold friction velocity $u_{*}^{T s}$ : the surface is smooth, and there are no non-erodible elements. On the other hand, for an increasing roughness length $z_{0}$, non-erodible elements are present: $f_{\text {eff }}$ tends to zero, increasing the value of $u_{*}^{T}$ and thus limiting the potential erodibility of the considered surface.

\subsection{The Wind Speed Distribution}

[35] Even if the current study uses prespecified wind speed over the whole domain in section 4 , the goal is to evaluate the mineral dust fluxes under realistic conditions. The model grid resolution is $1^{\circ} \times 1^{\circ}$, thus larger than the subgrid scale variability of observed winds.

[36] If the use of a mean wind speed value may have a limited impact on transport, this is not the case for saltation, this process being a wind-dependent threshold process. In order to taken into account this spatial subgrid scale wind variability, a Weibull distribution is implemented, following Cakmur et al. [2004] and Pryor et al. [2005]. The probability density function is expressed as follows:

$$
p(|U|)=\frac{k}{A}\left(\frac{|U|}{A}\right)^{k-1} \exp \left[-\left(\frac{|U|}{A}\right)^{k}\right]
$$

where $k$ is a dimensionless shape parameter (in our case $k=4$, a value commonly used to represent the wind variability over large surfaces). $A$ corresponds here to the mean modeled wind speed, in meters per second. In our case, this mean value corresponds to an hourly value, representative of the whole model grid cell.

\subsection{The Horizontal Saltation Fluxes}

[37] The parameterization of Marticorena and Bergametti [1995] estimates saltation fluxes using wind speed values and a complete description of the soil characteristics (dry size distribution of the loose erodible soil aggregates, soil humidity, vegetation cover, presence of non-erodible elements such as rocks on the surface). The calculation of the vertically integrated saltation flux is based on White's [1986] equation:

$$
F_{h}\left(D_{p}\right)=K \frac{\rho_{\mathrm{air}}}{g} u_{*}^{3}\left(1-\frac{u_{*}^{T}}{u_{*}}\right)\left(1+\frac{u_{*}^{T}}{u_{*}}\right)^{2}
$$

[38] Following the recommendation of Gomes et al. [2003], we use $K=1$ in our calculations. The air density is also considered as constant $\left(\rho_{\text {air }}=1.227 \mathrm{~kg} \mathrm{~m}^{-3}\right)$ for the idealized experiments in section 4 .

[39] Finally, the total saltation flux is obtained by integrat$\operatorname{ing} F_{h}$ over the soil size distribution from $D_{p}^{\min }=10^{-6} \mathrm{~m}$ to $D_{p}^{\max }=2.10^{-2} \mathrm{~m}$. This interval is chosen in order to cover the whole range of possible soil sizes. The final saltation flux is expressed as follows:

$$
F_{h}=\int_{D_{p}^{\min }}^{D_{p}^{\max }} F_{h}\left(D_{p}\right) \mathrm{d} S_{\text {rel }}\left(D_{p}\right) \mathrm{d} D_{p}
$$

$S_{\text {rel }}\left(D_{p}\right)$ being the relative surface distribution covered by particles with a mean mass median diameter $\mathrm{D}_{p}$ [Marticorena and Bergametti, 1995].

\subsection{The Vertical Sandblasting Fluxes}

[40] In order to estimate size resolved vertical dust fluxes, i.e., sandblasting fluxes, the Alfaro and Gomes [2001] DPM is used with the numerical optimization described in Menut et al. [2005]. The sandblasting flux is computed based on the partitioning of the kinetic energy of individual saltating aggregates and the cohesion energy of the populations of dust particles. This model assumes that dust emitted by sandblasting is characterized by three modes whose proportion depends on the wind friction velocity. From wind tunnel measurements performed on two natural soils from semi arid regions, Alfaro et al. [1998] consider these three modes as independent of the soil types. They described the three modes using log-normal distributions with diameters $d_{1}=1.5 \times 10^{-6} \mathrm{~m}, d_{2}=6.7 \times 10^{-6} \mathrm{~m}$, and $d_{3}=14.2 \times 10^{-6} \mathrm{~m}$ and their associated standard deviation, respectively $\sigma_{1}=1.7, \sigma_{2}=1.6$, and $\sigma_{3}=1.5$. Based on this model, as soil aggregate size or wind speed increases, kinetic energy becomes able to release first particles of the coarsest mode that are associated with the lowest cohesion energy, then particles from the intermediate population, and finally the finest particles. It also implies that for a specific wind speed and soil size distribution, the dust flux may be zero even if the saltation process occurs. In order to apportion the available kinetic energy between the three modes, a constant cohesion 

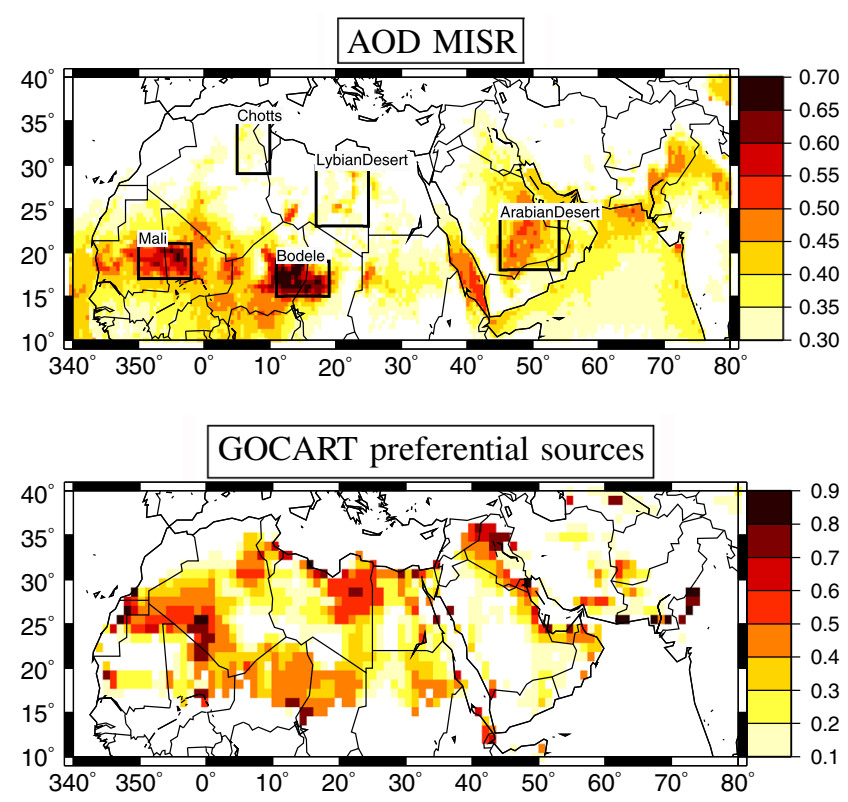

Figure 6. Main African dust sources. (top) The aerosol optical depth at $555 \mathrm{~nm}$ measured by MISR and averaged from February 2000 to December 2010, with a $0.5^{\circ} \times 0.5^{\circ}$ resolution. (bottom) The Goddard Chemistry Aerosol Radiation and Transport (GOCART) preferential sources, after Ginoux et al. [2001].

energy $e_{i}$ is associated to each mode values. The numerical values of $e_{i}$ were determined by adjusting the predicted aerosols size distribution to those measured in wind tunnel under different wind conditions, using an iterative least square routine. In this study, the values recommended by Alfaro and Gomes [2001] are used: $e_{1}=0.376, e_{2}=0.366$, and $e_{3}=0.346 \mathrm{~kg} \mathrm{~m}^{2} \mathrm{~s}^{-2}$.

[41] The kinetic energy is expressed as a function of the soil particle diameter after Alfaro et al. [1997] and Shao and $\mathrm{Lu}$ [2000]:

$$
e_{c}=\rho_{p} \frac{100 \pi}{3} D_{p}^{3}(u *)^{2}
$$

[42] It is compared to the cohesion energy of the three aerosol modes in order to compute the proportion $p_{i}\left(D_{p}\right)$ of these three modes in the total dust size distribution. By integrating equation (8) over the three aerosols modes, the total sandblasting flux may be written as follows:

$$
F_{v, m, i}\left(D_{p}\right)=\int_{D_{p}^{\min }}^{D_{p}^{\max }} \frac{\pi}{6} \rho_{p} \beta \frac{p_{i}\left(D_{p, i}\right) d_{m, i}^{3}}{e_{i}} \mathrm{~d} F_{h}\left(D_{p, i}\right)
$$

where $\mathrm{i}=1, N_{\text {class }}$ is the number of intervals discretizing the soil size distribution in the range $\left[D_{p}^{\min }: D_{p}^{\max }\right]$ and $d_{m, i}$ the mean mass diameter [Menut et al., 2005].

\section{Idealized Experiments}

\subsection{Experimental Setup}

[43] The sensitivity of the modeled mineral dust fluxes to different surface and soil descriptions is estimated over the simulation domain covering Northern Africa and Middle East. In this section, we consider spatially constant wind speeds for the analysis. The horizontal resolution was chosen to be the same for all calculations, $1^{\circ} \times 1^{\circ}$. For each of these configurations, the Alfaro and Gomes [2001] DPM is used, after its numerical optimization described in [Menut et al. Menut et al. [2005]]. We define three basic experiments:

[44] 1. NOfg: without the drag efficiency calculation and thus with $f_{\text {eff }}$ forced to 1 .

[45] 2. Feff: with the drag efficiency as described in equation (4).

[46] 3. GOpref: with a preferential source function. This approach was proposed partly due to the historical lack of roughness length [Ginoux et al., 2001] and has been widely used to specify the most erodible areas in models [Cakmur et al., 2006; Pérez et al., 2011]. In Figure 6 (bottom), the values represent a multiplicative factor, $\alpha$, with a horizontal resolution of $1^{\circ} \times 1^{\circ}$, ranging from 0 to 1 and built to enhance the representation of the most erodible surfaces. In this case, the vertical dust fluxes are calculated using $f_{\text {eff }}=1$ and $F_{v, \text { GOpref }}=\alpha \times F_{v}$.

[47] In addition to each of the previous experiments, we define three different uses of the roughness length and the soil types, as described in Figure 7.

[48] 1. LISA: represents the flux with the use of the LISA data set for the soil texture and the roughness length in the drag partition scheme.

[49] 2. ERS-LISA: represents the flux using the LISA-soil texture and the ERS satellite $z_{0}$ in the drag partition scheme.

[50] 3. ERS-SGF: represents the flux using the STATSGOFAO for the soil texture and the ERS satellite $z_{0}$ in the drag partition scheme.

[51] Note that the soil texture affects the threshold friction velocity through $\mathrm{z}_{0 s}$ which depends on the coarser soil particle population. It also affects the saltation flux through the relative surface area of the soil particles and the kinetic energy in the vertical flux though the soil particle diameter.

[52] The previous combinations lead to the calculation of nine different mineral dust fluxes. These nine configurations make possible to evaluate the relative sensitivities of the fluxes to the soil data sets and to the way of prescibing roughness over erodible surfaces. Thecomparisons between LISA and ERS-LISA are used to estimate the impact of the roughness length on the flux calculations. The comparisons between ERS-LISA and ERS-SGF are used to quantify the impact of the soil texture database on the flux calculations.

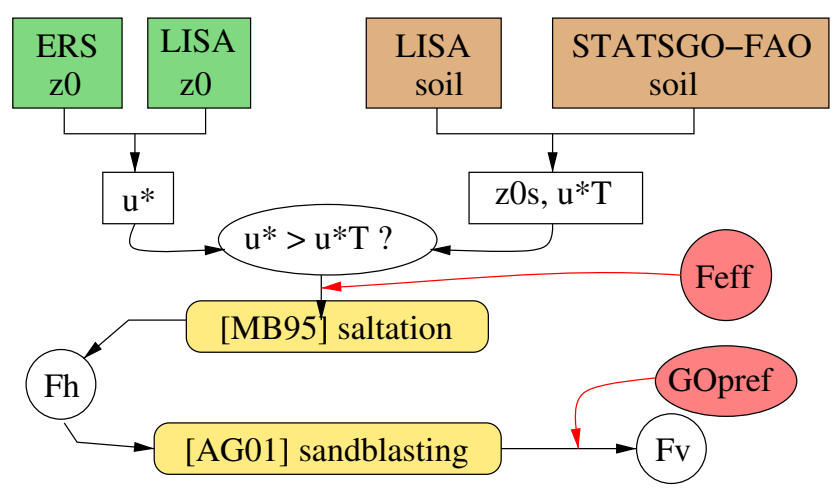

Figure 7. General flowchart of the model configurations used in this study. See details in section 4. The "Feff" and "GOpref" are optional and may be activated or not during the calculation. 
Table 3. Names and Coordinates of the Main Dust Sources Areas ${ }^{\mathrm{a}}$

\begin{tabular}{lcc}
\hline \multicolumn{1}{c}{ Area Name } & Longitude & Latitude \\
\hline Whole domain & $-16^{\circ} \mathrm{W} \rightarrow+77^{\circ} \mathrm{E}$ & $+13^{\circ} \mathrm{N} \rightarrow+36^{\circ} \mathrm{N}$ \\
Bodele & $+11^{\circ} \mathrm{W} \rightarrow+19^{\circ} \mathrm{W}$ & $+15^{\circ} \mathrm{N} \rightarrow+19^{\circ} \mathrm{N}$ \\
Mali & $-10^{\circ} \mathrm{W} \rightarrow-2^{\circ} \mathrm{W} ;$ & $+17^{\circ} \mathrm{N} \rightarrow+21^{\circ} \mathrm{N}$ \\
Chotts & $+5^{\circ} \mathrm{W} \rightarrow+10^{\circ} \mathrm{W}$ & $+29^{\circ} \mathrm{N} \rightarrow+35^{\circ} \mathrm{N}$ \\
Lybian Desert & $+17^{\circ} \mathrm{W} \rightarrow+25^{\circ} \mathrm{W}$ & $+23^{\circ} \mathrm{N} \rightarrow+30^{\circ} \mathrm{N}$ \\
Arabian Desert & $+45^{\circ} \mathrm{W} \rightarrow+54^{\circ} \mathrm{W}$ & $+18^{\circ} \mathrm{N} \rightarrow+24^{\circ} \mathrm{N}$ \\
\hline
\end{tabular}

${ }^{\text {a }}$ Defined for the results presentation and displayed in Figure 6.

[53] The main areas of analysis are displayed in Figure 6 (top) where the map represents the aerosol optical depth (AOD) at $555 \mathrm{~nm}$ measured by Multiangle Imaging Spectroradiometer (MISR) averaged from February 2000 to December 2010 at $0.5^{\circ} \times 0.5^{\circ}$ resolution. The MISR AOD represents both sources and dust load in the atmosphere after transport. However, it can be considered that the strongest regional AOD roughly coincides with the main dust sources. Among the sources, we highlight the well-known hot spots in the Bodele and eastern Niger, the Mali/Mauritania border, the Chotts, the Lybian desert, and the Arabian desert. In Figure 6 (top), the rectangles mark the areas for which the results are presented. Results are also presented for a larger domain encompassing the whole Saharan-Sahel region. This domain corresponds to the bounds within which the LISA data are available. Names and coordinates of the areas are given in Table 3.

\subsection{Results and Discussion}

\subsubsection{Horizontal Maps}

[54] Maps of surface fluxes for the nine configurations are displayed in Figure 8 for a spatially constant wind speed of $12 \mathrm{~m} / \mathrm{s}$. Note that all results are presented as a function of wind speed in contrast to other studies using friction velocity [e.g., Marticorena and Bergametti, 1995; Darmenova et al., 2009]. This choice is required for the present study since we analyze the impact of the roughness length which is also used in the calculation of the friction velocity.

[55] The NOfg experiment (Figure 8, left column) calculates emission fluxes which are considerably higher than those derived from the Feff and GOpref experiments. Also, the spatial variability is rather low over the whole domain displaying a poor correspondence with the dust hot spots detected by MISR. The worst configuration for this experiment is certainly LISA, which presents unrealistic fluxes over the Sahel and the northern part of the domain. When using the ERS roughness length, the results are more realistic with both LISA and STATSGO-FAO soils.

[56] For the Feff experiment (Figure 8, middle column), the LISA configuration represents fairly well the spatial variability of dust emission. ERS-LISA retains the major sources but appears to be more restrictive than LISA. ERS-SGF shows a close spatial variability to ERS-LISA due to the use of the same roughness length. However, the flux magnitudes are higher due to the different soil texture, which is smoother for the STATSGO-FAO soil than for the LISA soil.

[57] For the GOpref experiment (Figure 8, right column), the three configurations exhibit a rather close spatial variability showing that the fluxes in this case are mostly constrained by the $\alpha$ factor. In contrast to the Feff experiments, the preferential source enhances the fluxes in the border of Algeria with Mauritania and Mali and omits to a large extent the Mali/Mauritania border source.

[58] The results reflect that the use of a drag partition scheme strongly constrains the spatial distribution of fluxes and better matches the satellite dust distribution. The fluxes are also lower by a factor of 2 to 3 when using the drag partition scheme. Also, for a given soil data set, the fluxes estimated using the two roughness length data sets show significant differences in the spatial distribution, while for a given roughness length data set, the fluxes estimated using the two soil texture data sets show significant differences in the intensity of the fluxes. These points will be discussed in more detail in the next section.

\subsubsection{Distributions of Fluxes}

[59] Figure 9 shows a probability distribution of dust fluxes for the NOfg, Feff, and GOpref experiments. The flux values are represented with a step of $0.510^{-8} \mathrm{~g} \mathrm{~cm}^{-2} \mathrm{~s}^{-1}$. The occurrence refers to the fraction of grid cells where each dust flux value is estimated.

[60] All configurations show a strong positive skew (towards lower flux values). However, for all experiments, we notice that LISA displays significantly different distributions than ERS-LISA and ERS-SGF. With the LISA $z_{0}$, fluxes are less positively skewed and exhibit pronounced peaks in contrast to the smoother distributions observed in ERS-LISA and ERS-SGF.

[61] The NOfg experiment is less positively skewed than Feff and GOpref experiments. It clearly appears that Feff and GOpref act on the low flux values by decreasing the mode of the distributions from $10-15 \times 10^{8}$ to $1-3 \times 10^{8} \mathrm{~g} \mathrm{~cm}^{-2} \mathrm{~s}^{-1}$.

[62] The distributions for the Feff experiment reveal the impact of the soil and the roughness data sets on the intensity of the fluxes, with the roughness length data set having a stronger effect than the soil data set.

[63] The more comparable distributions are obtained with the GOpref experiment. The weight of the preferential source constrains the distributions to similar values between 0 and $5 \times 10^{-8} \mathrm{~g} \mathrm{~cm}^{-2} \mathrm{~s}^{-1}$ with the ERS $z_{0}$ and between 0 and $15 \times 10^{-8} \mathrm{~g} \mathrm{~cm}^{-2} \mathrm{~s}^{-1}$ with the LISA $z_{0}$.

\subsubsection{Relative Impact of $z_{0}$ Distributions}

[64] Figure 10 presents distributions of aeolian roughness length, $z_{0}$, over the whole African domain for the two data sets, LISA and ERS. Since the LISA data set is based on geomorphological considerations and measurement data, $z_{0}$ values are prescribed for some specific land types, and thus, only "discrete" values are available. On the other hand, the ERS $z_{0}$ values are estimated from satellite measurements, exhibiting a continuous spectrum of values and a maximum $z_{0}$ of $0.08 \mathrm{~cm}$. It is obvious that, to describe physical characteristics, a continuous spectrum is more realistic than some few discrete values, and in the case of mineral dust flux calculations, this leads to large differences since the parameterizations used are based on a threshold approach.

[65] To better quantify this "discrete values" effect, Figure 11 presents a probability distribution of the drag efficiency, $f_{\text {eff }}$, for LISA, ERS-LISA, and ERS-SGF at the prespecified wind speed of $12 \mathrm{~m} / \mathrm{s}$. Occurrence is calculated with a step of 0.01 . This representation explains the main differences diagnosed in the flux calculations. Since the LISA $z_{0}$ data set used only a few different values of $z_{0}$, the corresponding $f_{\text {eff }}$ also exhibit a few discrete values. On the other 

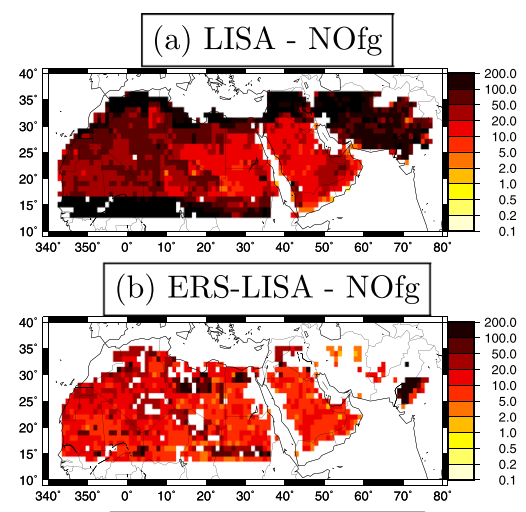

(c) ERS-SGF - NOfg

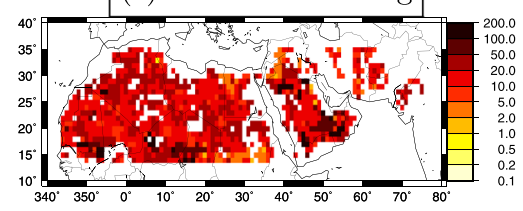

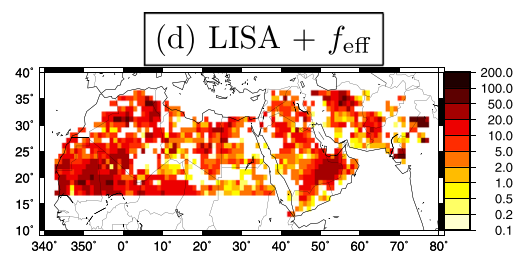
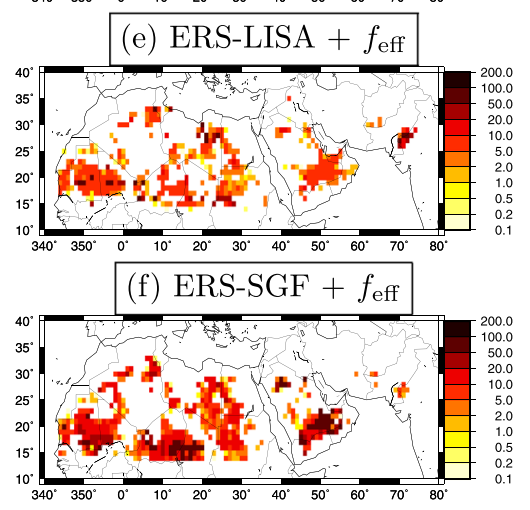

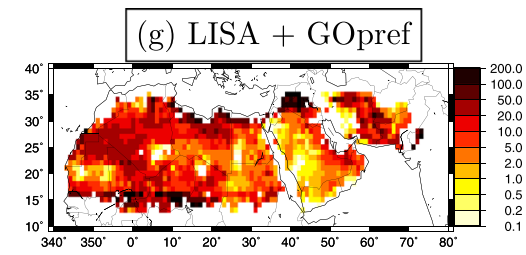

(h) ERS-LISA + GOpref

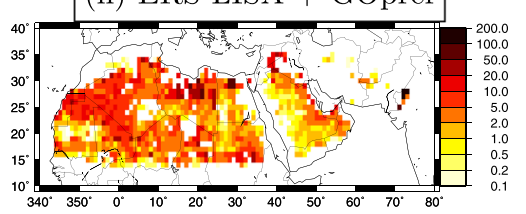

(i) ERS-SGF + GOpref

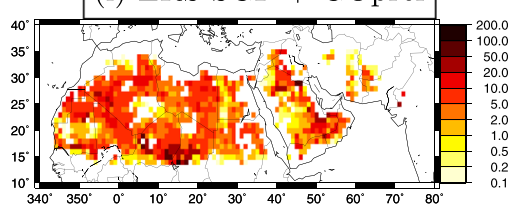

Figure 8. Mineral dust vertical fluxes $\left(10^{-8} \mathrm{~g} \mathrm{~cm}^{-2} \mathrm{~s}^{-1}\right)$ calculated with a prespecified wind speed of $12 \mathrm{~m} / \mathrm{s}$ with the model configurations LISA, ERS-LISA, and ERS-SGF, (left) with no drag efficiency or preferential source use, called NOfg, (middle) using the drag efficiency $f_{\text {eff }}$ scheme, and (right) using the GOCART preferential sources, noted GOpref. Note that the color scale is exponential.

hand, when $f_{\text {eff }}$ is estimated with the ERS $z_{0}$, the $f_{\text {eff }}$ is more continuous and more physically realistic. Also, there is a minimum drag efficiency with the ERS $z_{0}$ of about 0.3 which explains the more restrictive regions of emission displayed in Figure 8.

\subsubsection{Fluxes Over Specific Areas}

[66] For all configurations, the dust production model was run with spatially constant wind speed values, from 0 to $24 \mathrm{~m} / \mathrm{s}$ with a step of $1 \mathrm{~m} / \mathrm{s}$. Results were spatially integrated over specific source regions, and the results are displayed in Figure 12. An integration of fluxes over the whole domain simulation is referred to as "ALL."

[67] The fluxes with the configuration LISA tend to be higher than those obtained with the ERS $z_{0}$ (with both ERSLISA and ERS-SGF). This is observed for the whole domain ("ALL") integration and for some specific regions, even if this tendency is lower over Bodélé and the Lybian and Arabian deserts. Another general tendency is that the fluxes without drag efficiency (NOfg, GOpref), are significant at very low wind speeds $(2-6 \mathrm{~m} / \mathrm{s})$. In arid regions, modeled emissions fluxes are often close to zero below $10 \mathrm{~m}$ wind speeds of 7-8 m/s [Menut et al., 2005]. This effect is clearly emphasized with the LISA configuration and is certainly unrealistic. The same applies for ERS-LISA and ERS-SGF but to a lesser extent. Globally, the omission of a drag partition scheme gives unrealistic emission fluxes for wind speeds between 4 and $8 \mathrm{~m} / \mathrm{s}$. For wind speed values up to $8 \mathrm{~m} / \mathrm{s}$, the configurations NOfg and GOpref produce higher fluxes than Feff for all regions.

\section{Real Case Study}

[68] In order to evaluate model configurations with realworld data, we simulated the period 1 March to 31 July 2011 using the WRF and CHIMERE models. The modeled dust concentration fields were used to estimate the Aerosol
Optical Depth (AOD) which was compared to Aerosol Robotic Network (AERONET) Sun photometer measurements. In this section, we first describe the dust transport model and the observations used. Results are presented under the form of time series and AOD maps and are discussed using skill scores.

\subsection{Model Setup and Observations}

\subsubsection{The WRF and CHIMERE Models}

[69] Two models are used in this study: the meteorological fields are calculated using the Weather Research and Forcasting (WRF) model [Skamarock et al., 2007], and the mineral dust transport is calculated with the CHIMERE chemistry-transport model in its mineral dust configuration [Menut et al., 2009].

[70] The meteorological analysis data of NCEP [Kalnay et al., 1996] are provided on a regular $1.125^{\circ} \times 1.125^{\circ}$ grid. These fields are used as boundary conditions and nudging for WRF in its 3.2.1 version. The model is used in its nonhydrostatic configuration. The horizontal grid of $180 \times 102$ grid points in longitude and latitude is used with a Lambert projection to ensure a regular grid spacing of $\Delta x=\Delta y=$ $100 \mathrm{~km}$. The vertical grid covers 32 levels from the surface to $50 \mathrm{hPa}$, and the integration time step is $4 \mathrm{~min}$. For the microphysics, the WRF Single Moment-5 class scheme is used allowing for mixed phase processes and supercooled water [Hong et al., 2004]. The radiation scheme is RRTMG scheme [Mlawer et al., 1997]. The surface physics is calculated using the Noah Land Surface Model scheme with four soil temperature and moisture layers [Chen and Dudhia, 2001]. The planetary boundary layer physics is processed using the Yonsei University scheme [Hong et al., 2006], and the cumulus parameterization uses the ensemble scheme of Grell and Devenyi [2002].

[71] The CHIMERE chemistry-transport model may be used for urban to regional air pollution (including 

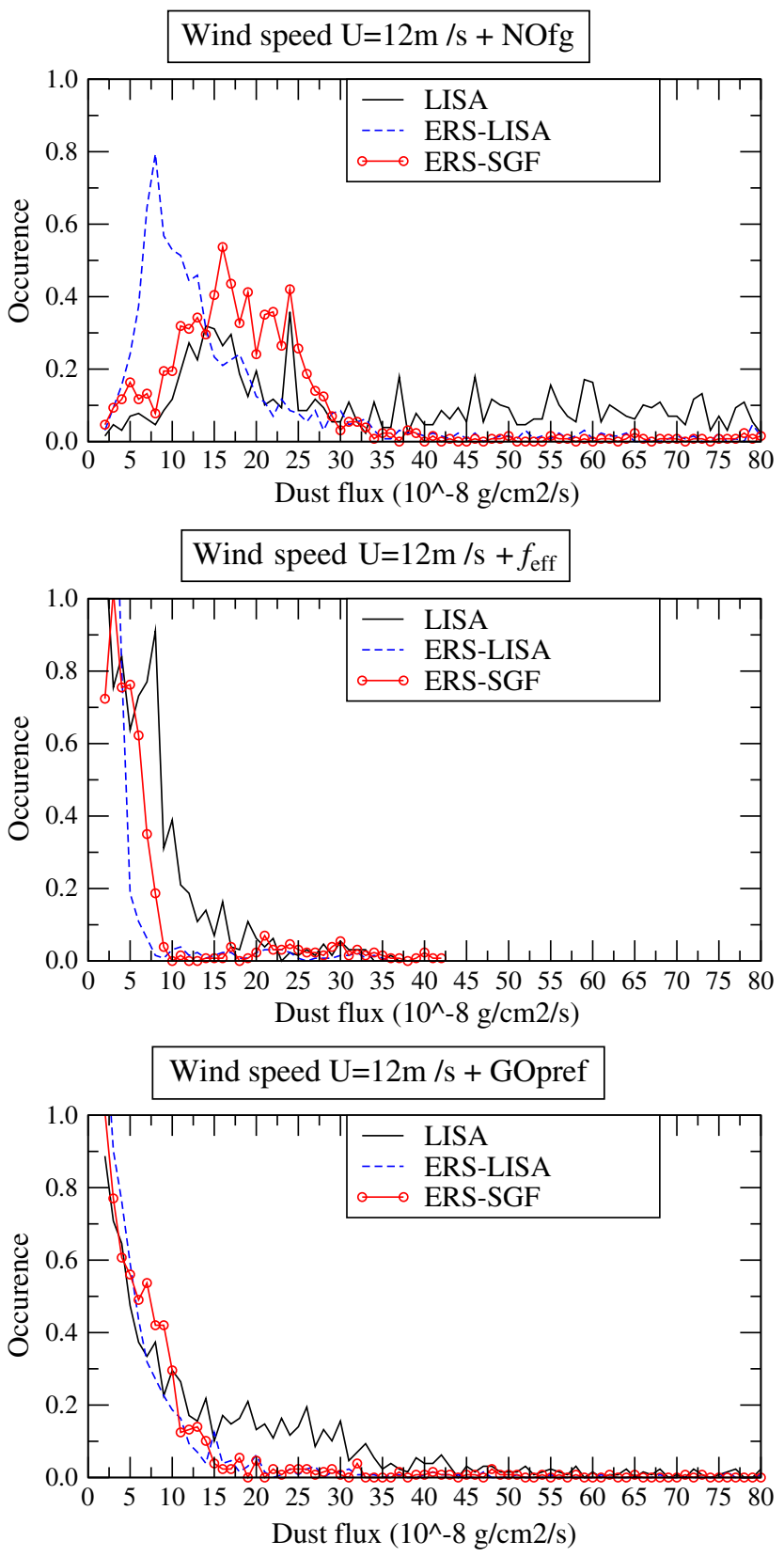

Figure 9. Distribution of vertical dust fluxes calculated with several model configurations and for a prespecified and constant wind speed of $12 \mathrm{~m} / \mathrm{s}$. The calculations are done with a step of $0.1 \times 10^{-8} \mathrm{~g} \mathrm{~cm}^{-2} \mathrm{~s}^{-1}$ for the dust flux. The occurrence represents the number of grid cells where each dust flux value was estimated.

anthropogenic and biogenic emissions [Bessagnet et al., 2010]), for analysis and forecast [Menut and Bessagnet, 2010], and for long-range transport [Menut et al., 2009]. In this study, the model is used with only the mineral dust emissions and transport. The domain covers the area $\left(-56^{\circ}\right.$ $<$ longitude $\left.<+38^{\circ}\right)$ and $\left(+2^{\circ}<\right.$ latitude $\left.<+54^{\circ}\right)$. It takes into account the processes that drive the main phases of the dust cycle: saltation and sandblasting for emissions calculations, horizontal advection, and vertical transport, including advection and mixing. The boundary layer parameterization

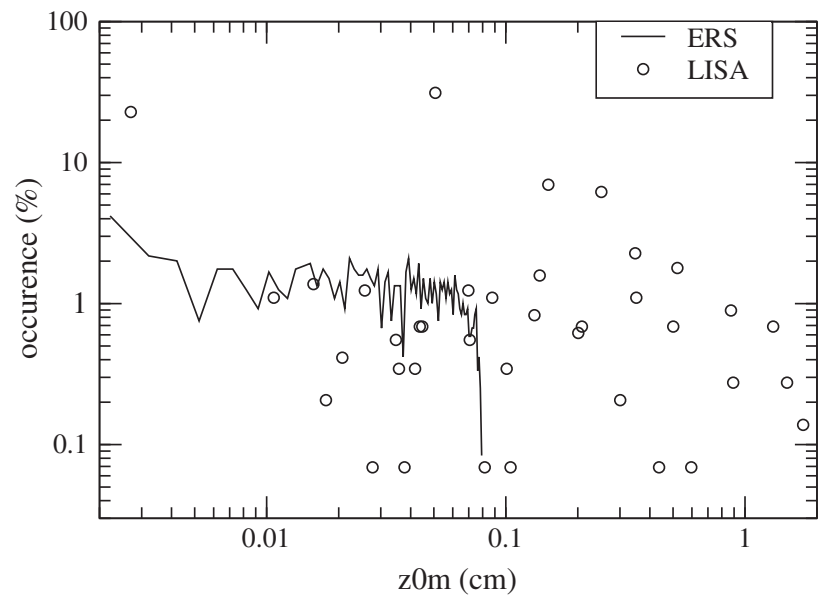

Figure 10. Distribution of eolian roughness lengths, $z_{0}$ (in $\mathrm{cm})$, over the whole African domain for the LISA and ERS data sets.

is the one of Troen and Mahrt [1986]. Dry and wet deposition are treated as described in Wesely [1989] and Loosmore and Cederwall [2004]. The horizontal resolution is $1^{\circ} \times 1^{\circ}$ with 20 vertical levels (hourly dependent on the pressure) from the surface to $200 \mathrm{hPa}$. The calculation time step is $10 \mathrm{~min}$, and the results are stored every hour for analysis. Model characteristics are explained in Menut et al. [2007]. In order to be realistic for this simulation, the configuration Feff is used for the three soil and surface data sets.

\subsubsection{AERONET Optical Thickness Measurements}

[72] The AERONET stations [Holben et al., 2001] used are listed in Table 4. Figure 13 shows the stations' locations. Data are extracted from the NASA website in their 1.5 version that includes cloud screening. The retained stations were chosen to represent both sites close to important sources (Banizoumbou, Cinzana, Ilorin, Dakar) and sites more representative of midrange dust transport (Capo Verde, Izana, Blida, and Lampedusa).

\subsection{Results}

[73] Figure 13 presents horizontal maps of AOD. Hourly values are averaged over 5 days and only for hours 9:00,

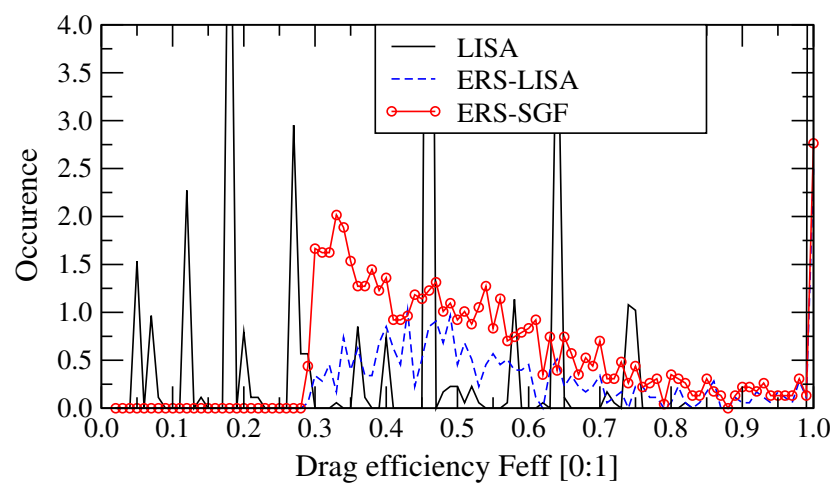

Figure 11. Distribution of the drag efficiency $f_{\text {eff }}$ calculated for the three model configurations and a prespecified wind speed of $12 \mathrm{~m} / \mathrm{s}$. 

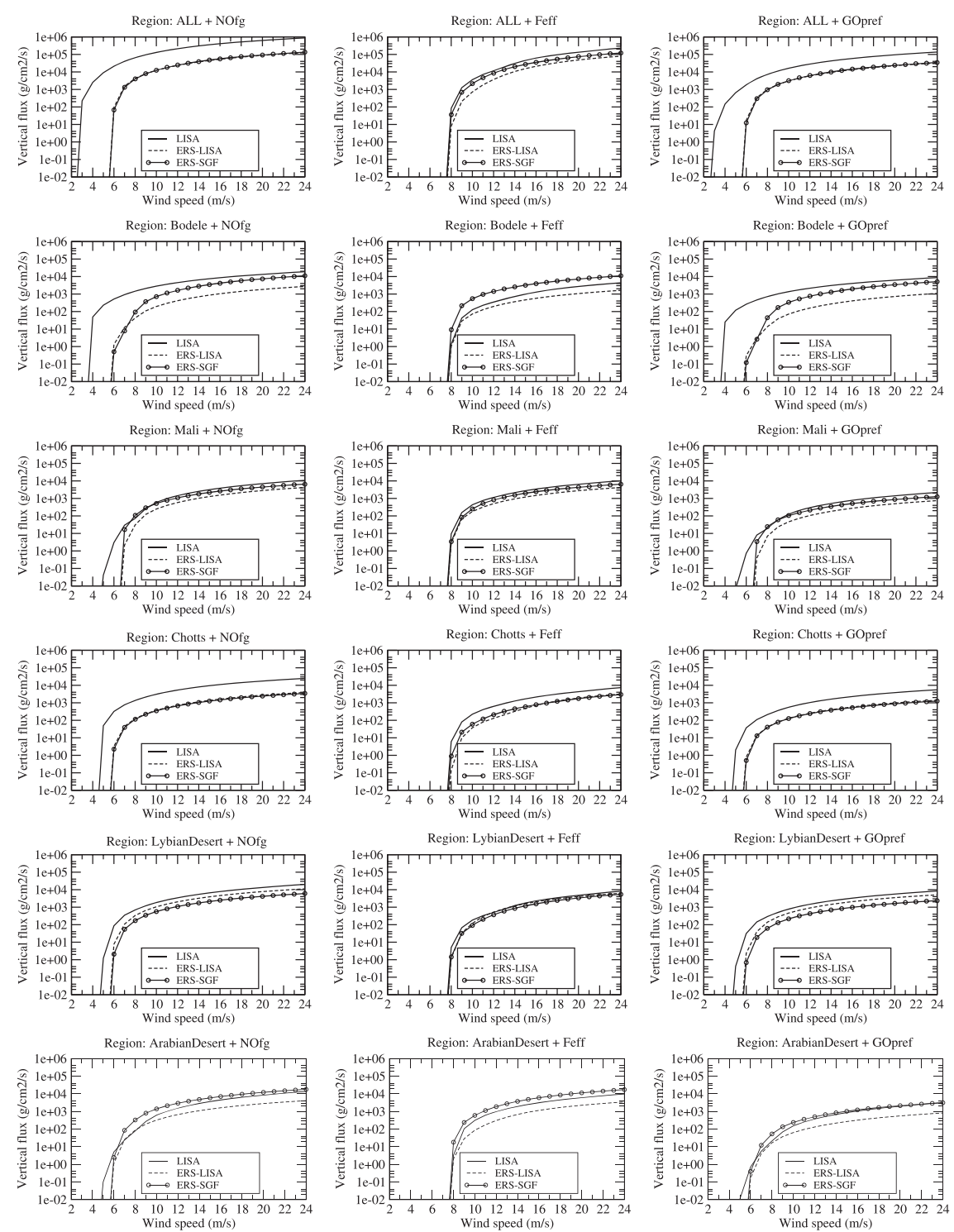

Figure 12. Mineral dust fluxes $\left(10^{-8} \mathrm{~g} \mathrm{~cm}^{-2} \mathrm{~s}^{-1}\right)$, accumulated over specific source regions and for the three model configurations LISA, ERS-LISA, and ERS-SGF. (left) With no drag efficiency or preferential source used, (middle) using the drag partition scheme, and (right) with the GOCART preferential source.

10:00, and 11:00 to produce one single map comparable to MODIS Terra satellite data.

[74] Two different periods are presented: 30 April to 4 May 2011 and 6-11 June 2011. The top panel corresponds to the MODIS satellite aerosol optical at $550 \mathrm{~nm}$. The modeled AOD was also calculated at $550 \mathrm{~nm}$ for this comparison to MODIS. The other panels correspond (from top to bottom) to the LISA, ERS-LISA, and ERS-SGF model configurations. For the two periods, and even if no satellite data are available over the middle of Africa, the observed AOD highest values are well localized with the model. For the first period (30 April to 4 May), the main active sources are the Lybian desert, Bodele, and the Chotts region. The comparison between LISA and ERS-LISA shows similar spatial patterns with the dust content being higher towards the Mediterranean. As shown in the previous section, the ERS $z_{0}$ provides more limited emission areas for a given wind speed, and the maxima are lower. The relative patterns between north and south significantly differ with ERS-SGF compared to the LISA configurations. In this case, the Bodele region shows higher AOD than the Mediterranean region.

[75] For the stations listed in Table 4, AOD time series at $440 \mu \mathrm{m}$ are compared with AERONET data, Figure 14. At Banizoumbou (Nigeria), Zinder (Nigeria), and Cinzana

Table 4. Names and Coordinates of the AERONET Surface Stations Displayed in Figure 13

\begin{tabular}{lcc}
\hline \multicolumn{1}{c}{ Station } & Longitude & Latitude \\
\hline Banizoumbou & $+2.66^{\circ} \mathrm{E}$ & $+13.54^{\circ} \mathrm{N}$ \\
Capo Verde & $-22.93^{\circ} \mathrm{W}$ & $+16.73^{\circ} \mathrm{N}$ \\
Cinzana & $-5.93^{\circ} \mathrm{W}$ & $+13.28^{\circ} \mathrm{N}$ \\
Dakar & $-16.95^{\circ} \mathrm{W}$ & $+14.39^{\circ} \mathrm{N}$ \\
Lampedusa & $+12.63^{\circ} \mathrm{E}$ & $+35.52^{\circ} \mathrm{N}$ \\
Zinder & $+8.98^{\circ} \mathrm{E}$ & $+13.75^{\circ} \mathrm{N}$ \\
\hline
\end{tabular}



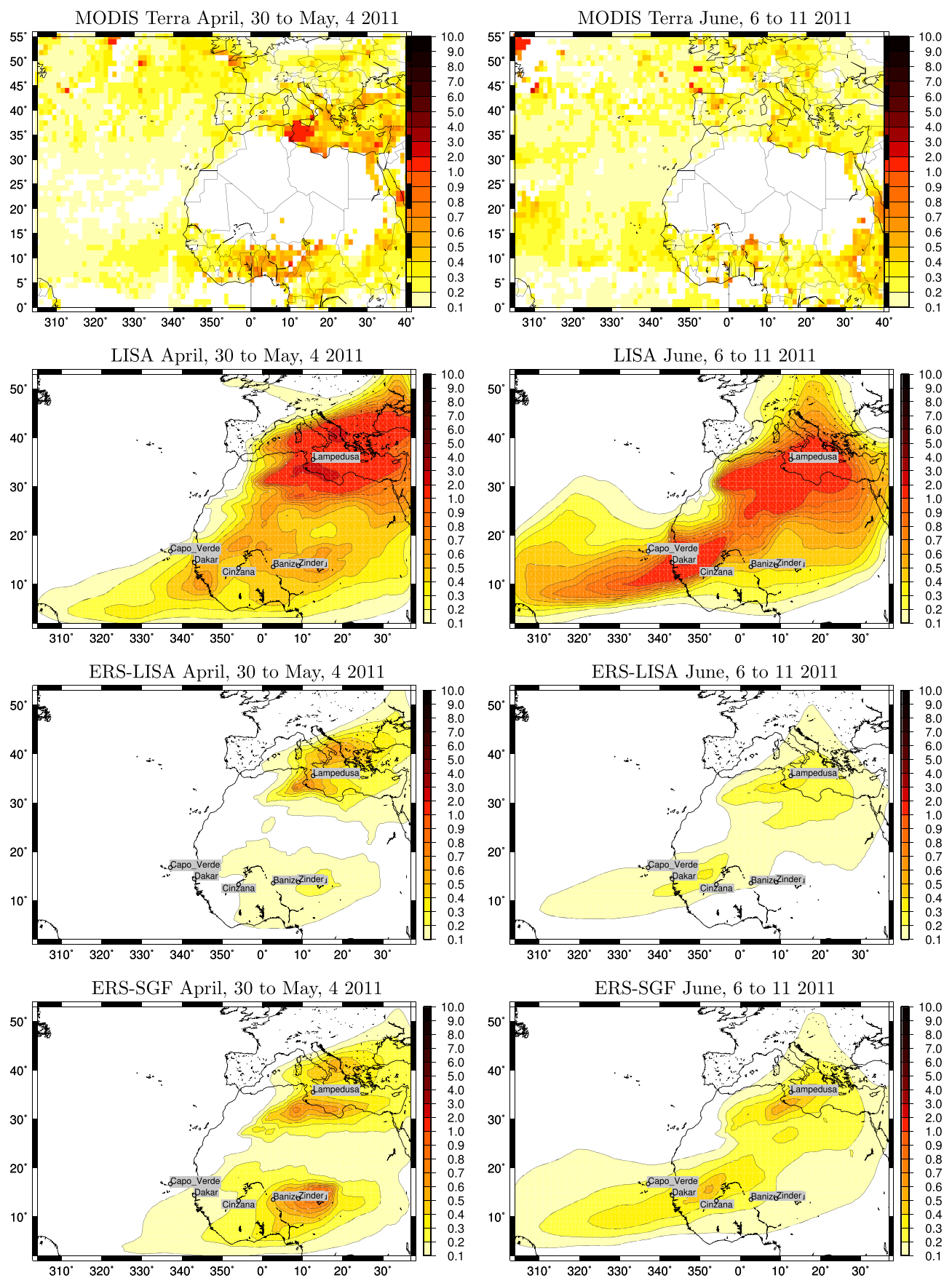

Figure 13. Mean averaged values of AOD during periods of 5 days, starting with 30 April 2011 and 6 June 2011. The MODIS Terra optical depth at $\lambda=550 \mathrm{~nm}$ are extracted from the NASA Giovanni tool. The LISA, ERS-LISA, and ERS-SGF are modeled aerosol optical depth $(\lambda=550 \mathrm{~nm})$ with WRF and CHIMERE.

(Mali), which are close to mineral dust sources in the south, the AOD values are higher than over the other sites, with measured peaks reaching values up to 2 . While the LISA and ERS-SGF configurations reproduce the observed variability between 0 and 2, the ERS-LISA configuration AOD remains below 0.5. This remark is valid for all sites.

[76] Dakar is located at the West African coast and Sal/Cape Verde about $600 \mathrm{~km}$ off the West African coast.
For these two locations, the LISA configuration estimates higher concentrations than the two other configurations and the observed AOD. The ERS-SGF configuration is the one that better captures the AOD at these two stations. At the Lampedusa station (Italy, $150 \mathrm{~km}$ off the Tunesian coast), the measured AOD values are rather low (0.5 in average) and representative of long-range transport of dust. Here, the three configurations show a strong variability, and it is difficult to qualitatively conclude on the most suitable configuration. 

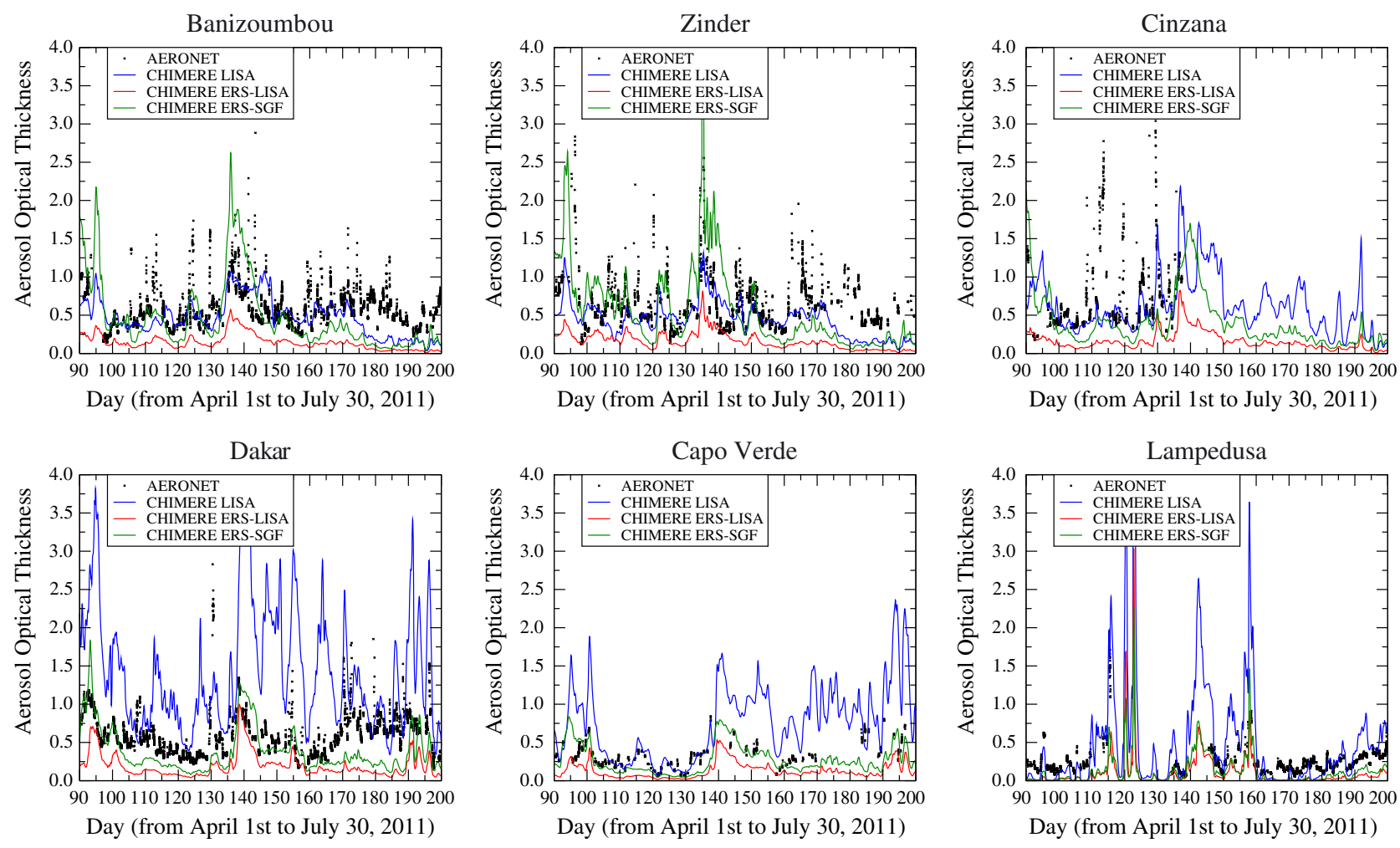

Figure 14. Time series of aerosol optical depth $(\lambda=440 \mathrm{~nm})$, measured with the sumphotometers of the AERONET network and modeled with CHIMERE and the several dust emissions data sets.

[77] Statistical scores are calculated over the period of 1 March to 1 July 2011. Table 5 presents these results with the following statistical indicators for each station:

[78] 1. Correlation:

$$
\text { Cor }=\frac{\sum_{i=1}^{N}\left(M_{i}-\bar{M}\right) \cdot\left(O_{i}-\bar{O}\right)}{\sqrt{\sum_{i=1}^{N}\left(M_{i}-\bar{M}\right)^{2}} \cdot \sqrt{\sum_{i=1}^{N}\left(O_{i}-\bar{O}\right)^{2}}}
$$

[79] 2. Mean normalized bias error (MNBE):

$$
\operatorname{MNBE}=\frac{1}{N} \sum_{i=1}^{N}\left(\frac{M_{i}-O_{i}}{O_{i}}\right) \times 100
$$

[80] 3. Root mean square error (RMSE):

$$
R M S E=\sqrt{\frac{1}{N} \sum_{i=1}^{N}\left(M_{i}-O_{i}\right)^{2}}
$$

where $M$ and $O$ represent the modeled and mesured AOD, respectively, with an hourly frequency (corresponding to the model output). $\bar{M}$ and $\bar{O}$ represent the time-averaged AOD for the model and the measurements, respectively. The $N$ values correspond to the number of values for which AERONET data are available, which differs from one station to another. The best values of correlation and MNBE are in bold for each station to show the most accurate model configuration.

[81] The mean bias (MNBE) is expressed in percent and ranges from $-73 \%$ to $+175 \%$. This indicator has to be carefully analyzed because the bias is directly dependent on the model dust size-distribution discretization (the number of bins and their values) and on the distribution of emissions in the model modes. It means that a correlation is more model dependent than a real indicator of a good (or not) modeling. But this may globally express the range between a model and observations. For the three model configurations, the biases are quite comparative and mainly show that all model configurations are able to give the correct order of magnitude

\begin{tabular}{|c|c|c|c|c|c|c|c|c|c|c|c|c|c|c|}
\hline \multirow[b]{2}{*}{ Site } & \multirow[b]{2}{*}{$N_{\text {val }}$} & \multirow[b]{2}{*}{$\bar{O}$} & \multicolumn{3}{|c|}{$\bar{M}$} & \multicolumn{3}{|c|}{ RMSE } & \multicolumn{3}{|c|}{ Cor } & \multicolumn{3}{|c|}{ MNBE } \\
\hline & & & LI & EL & ES & LI & EL & ES & $\mathrm{LI}$ & EL & ES & LI & EL & ES \\
\hline Banizoumbou & 1068 & 0.66 & 0.47 & 0.17 & 0.74 & 0.41 & 0.57 & 0.56 & 0.18 & 0.49 & 0.50 & -15.73 & -70.99 & 14.32 \\
\hline Zinder & 826 & 0.68 & 0.46 & 0.20 & 0.84 & 0.43 & 0.60 & 0.65 & 0.36 & 0.44 & 0.37 & -17.71 & -66.11 & 39.64 \\
\hline Cinzana & 583 & 0.76 & 0.50 & 0.18 & 0.65 & 0.58 & 0.74 & 0.64 & 0.21 & 0.32 & 0.27 & -19.07 & -73.91 & -6.30 \\
\hline Capo Verde & 450 & 0.26 & 0.47 & 0.08 & 0.19 & 0.38 & 0.20 & 0.14 & 0.71 & 0.74 & 0.68 & 67.81 & -70.59 & -27.05 \\
\hline Dakar & 1132 & 0.54 & 1.35 & 0.18 & 0.38 & 1.11 & 0.44 & 0.34 & 0.37 & 0.45 & 0.47 & 175.49 & -65.47 & -28.25 \\
\hline Lampedusa & 671 & 0.24 & 0.27 & 0.05 & 0.08 & 0.29 & 0.23 & 0.20 & 0.74 & 0.68 & 0.74 & -3.94 & -81.45 & -72.46 \\
\hline
\end{tabular}
for the AOD.

Table 5. Statistical Scores for the AOD Modelinga

${ }^{a}$ Compared to the AERONET measurements (for $\lambda=440 \mathrm{~nm}$ ). The letters correspond to "LI" for LISA, "EL" for ERS-LISA, and "ES" for ERS-SGF. 
[82] The correlations, "Cor" in Table 5, range from 0.18 to 0.74 , depending on the site and the model configuration. This indicator is much appropriate to the discussion of this study, because this is the direct expression of the ability of different modeled sources to be well represented with a realistic meteorology and after transport in the atmosphere. For the LISA configuration, the correlation ranges from 0.18 to 0.74, for ERS-LISA from 0.32 to 0.74 , and for ERS-SGF from 0.27 to 0.74 . The high values are not estimated for the same sites, but it is noticeable that the best correlations are calculated for Lampedusa and Capo Verde sites, after transport. The correlations shows that the three model configurations are able to produce realistic transport and AOD. This is already known for the LISA data set being used in many dust models. With these scores, we show that this is also possible to have good model results with a new data set such as ERS-SGF.

[83] The RMSE expresses the model variability compared to observations. It varies from 0.29 to 1.11 with LISA, from 0.2 to 0.74 for ERS-LISA, and from 0.2 to 0.65 for ERS-SGF, showing that the model variabilities are comparable between the data sets, the ERS-SGF having the lowest values.

\section{Summary and Conclusions}

[84] In this paper, mineral dust emission fluxes modeled over Northern Africa were compared when using different roughness and soil texture data sets. For all comparisons, we used the dust production model of Alfaro and Gomes [2001].

[85] Numerous dust modeling studies exist for Northern Africa and the Sahel regions. One of the most known and widely used soil (texture) and surface $\left(z_{0}\right.$, the roughness length) data sets is the one proposed by LISA and described in Marticorena and Bergametti [1995], with $1^{\circ} \times 1^{\circ}$ horizontal resolution. Data were estimated from field campaigns and geomorphological analyses.

[86] We analyzed the sensitivity of an advanced emission scheme in Northern Africa by comparing the LISA data set to global estimates of soil texture (STATSGO-FAO) and roughness length (USGS and ERS). USGS values for roughness length depend on land use types, and although they have been widely used in atmospheric modeling, their application is limited for dust modeling purposes. ERS are more recent estimates of roughness length from satellite data and are more appropriate for dust modeling.

[87] Three surface and soil data sets are thus defined, following Figure 7: the original LISA data set, the LISA data set but with the ERS roughness length (ERS-LISA), and the USGS and STATSGO surface and soil data sets with the ERS roughness length (ERS-SGS). I addition, we also analyzed the impact of the drag partition efficiency process in the dust emission scheme and compared its behavior within the model to a widely used preferential source approach [Ginoux et al., 2004].

[88] First, and in order to quantify the differences between modeled emissions fluxes that are only due to the surface and soil characteristics, we defined idealized experiments by using a prespecified constant wind speed over the whole domain. Having no direct emission flux measurements, comparisons were done among the configurations. The use of the drag partition scheme is able to fairly well constrain the spatial distribution of the sources with both LISA and ERS roughness lengths. The LISA dust fluxes are, on average, higher than the other model configurations. This is mainly due to the distribution of $z_{0}$ values: being tabulated, values are more discrete and thus less variable and realistic than those provided by ERS from satellite data. Concerning the soil texture, the STATSGO-FAO soil data set is realistic enough to make possible fluxes calculations over the whole domain. It was also shown that without a drag partition scheme, fluxes are unrealistic. The use of a preferential sources approach replacing the drag partition scheme is able to match the spatial distribution of important sources areas. However, this approach does not allow constraining realistically the threshold friction velocity with the emission scheme used, since fluxes are too high for low wind speeds.

[89] Second, the three soil and surface data set configurations were used to model the period of March to July 2011 over a domain encompassing Northern Africa and southern Europe. The models used were WRF for meteorology and CHIMERE for the dust transport. The simulations were compared to AOD measured at several AERONET stations in the region and to MODIS satellite data. The evaluation showed that the new configuration ERS-SGF is able to accurately reproduce the main dust sources and the AOD variability in the region.

[90] The next steps for these studies will be to compare modeled dust fluxes calculated with the ERS data used in this study $\left(0.25^{\circ} \times 0.25^{\circ}\right.$ [Prigent et al., 2005] $)$ to the recent data set presented in Prigent et al. [2012] $(6 \mathrm{~km} \times 6 \mathrm{~km})$ and thus to explore the impact of the model horizontal resolution on emission dust fluxes magnitude and size distribution. Another perspective is how to use this global data set to extend the dust emissions domain to estimate the impact of local erosion on the budget of surface particulate matter in Europe, following the study of Bessagnet et al. [2008] about the dust source in Ukraine. Finally, the ability to model dust emissions fluxes at the same time in Africa and Europe would improve the previsibility of particles and thus improve the short-term forecast of air quality, as discussed in Menut and Bessagnet [2010].

[91] Acknowledgments. This study was partly funded by the French Ministry in charge of Ecology. We thank the principal investigators and their staff for establishing and maintaining the AERONET sites used in this study: Didier Tanré for Banizoumbou, Capo Verde and Dakar; Bernadette Chatenet and Jean-Louis Rajot for Zinder and Cinzana; and Daniela Meloni for Lampedusa.

\section{References}

Alfaro, S. C., and L. Gomes (2001), Modeling mineral aerosol production by wind erosion: Emission intensities and aerosol size distribution in source areas, J. Geophys. Res., 106, 18,075-18,084.

Alfaro, S. C., A. Gaudichet, L. Gomes, and M. Maillé (1997), Modeling the size distribution of a soil aerosol produced by sandblasting, J. Geophys. Res., 102, 11,239-11,249.

Alfaro, S. C., A. Gaudichet, L. Gomes, and M. Maillé (1998), Mineral aerosol production by wind erosion: Aerosol particle sizes and binding energies, Geophys. Res. Lett, 25, 991-994.

Bessagnet, B., L. Menut, G. Aymoz, H. Chepfer, and R. Vautard (2008), Modelling dust emissions and transport within Europe: The Ukraine March 2007 event, J. Geophys. Res., 113, D15202, doi: 10.1029/2007JD009541.

Bessagnet, B., C. Seigneur, and L. Menut (2010), Impact of dry deposition of semi-volatile organic compounds on secondary organic aerosols, Atmos. Environ., 44, 1781-1787, doi:10.1016/j.atmosenv.2010.01.027.

Cakmur, R. V., R. L. Miller, and O. Torres (2004), Incorporating the effect of small-scale circulations upon dust emission in an 
atmospheric general circulation model, J. Geophys. Res., 109, D07201, doi:10.1029/2003JD004067.

Cakmur, R. V., R. L. Miller, J. Perlwitz, I. Geogdzhayev, P. Ginoux, D. Koch, K. Kohfeld, I. Tegen, and C. Zender (2006), Constraining the magnitude of the global dust cycle by minimizing the difference between a model and observations, J. Geophys. Res., 111, D06207, doi: 10.1029/2005JD005791

Callot, Y., B. Marticorena, and G. Bergametti (2000), Geomorphologic approach for modelling the surface features of arid environments in a model of dust emissions: Application to the Sahara desert, Geodin. Acta, 13, 245-270.

Chatenet, B., B. Marticorena, L. Gomes, and G. Bergametti (1996), Assessing the microped size distributions of desert soils erodible by wind, Sedimentology, 43, 901-911.

Chen, F., and J. Dudhia (2001), Coupling an advanced landsurface/hydrology model with the penn state NCARMM5 modeling system. Part I: Model implementation and sensitivity, Mon. Wea. Rev., 129, 569-585.

Cheng, T., Y. Peng, J. Feichter, and I. Tegen (2008), An improvement on the dust emission scheme in the global aerosol-climate model ECHAM5HAM, Atmos. Chem. Phys., 8(4), 1105-1117, doi:10.5194/acp-8-11052008.

Darmenova, K., I. N. Sokolik, Y. Shao, B. Marticorena, and G. Bergametti (2009), Development of a physically based dust emission module within the Weather Research and Forecasting (WRF) model: Assessment of dust emission parameterizations and input parameters for source regions in Central and East Asia, J. Geophys. Res., 114, D14201, doi:10.1029/2008JD011236

Ginoux, P., M. Chin, I. Tegen, J. Prospero, B. Holben, O. Dubovik, and S Lin (2001), Sources and distributions of dust aerosols simulated with the GOCART model, J. Geophys. Res., 106, 20,255-20,273.

Ginoux, P., J. M. Prospero, O. Torres, and M. Chin (2004), Long-term simulation of global dust distribution with the GOCART model: Correlation with North Atlantic oscillation, Environ. Modell. Softw., 19, 113-128.

Gomes, L., J. L. Rajot, S. C. Alfaro, and A. Gaudichet (2003), Validation of a dust production model from measurements performed in semi-arid agricultural areas of Spain and Niger, Catena, 52, 257-271.

Grell, G. A., and D. Devenyi (2002), A generalized approach to parameterizing convection combining ensemble and data assimilation techniques, Geophys. Res. Lett., 29(14), 1693, doi:10.1029/2002GL015311.

Grini, A., G. Myhre, C. S. Zender, and I. Isaksen (2005), Model simulations of dust sources and transport in the global atmosphere: Effects of soil erodibility and wind speed variability, J. Geophys. Res., 110, D02205, doi:10.1029/2004JD005037.

Holben, B., et al. (2001), An emerging ground-based aerosol climatology: Aerosol Optical Depth from AERONET, J. Geophys. Res., 106 12,067-12,097.

Hong, S. Y., J. Dudhia, and S. Chen (2004), A revised approach to ice microphysical processes for the bulk parameterization of clouds and precipitation, Mon. Weather Rev., 132, 103-120.

Hong, S. Y., Y. Noh, and J. Dudhia (2006), A new vertical diffusion package with an explicit treatment of entrainment processes, Mon. Weather Rev. 134, 2318-2341, doi:10.1175/MWR3199.1.

Huneeus, N., et al. (2011), Global dust model intercomparison in AeroCom phase I, Atmos. Chem. Phys., 11, 7781-7816.

Janjic, Z. (1994), The step-mountain eta coordinate model: Further developments of the convection, viscous sublayer, and turbulence closure schemes, Mon. Wea. Rev., 122, 927-945.

Kalnay, E., et al. (1996), The NCEP/NCAR 40-year reanalysis project, Bull. Amer. Meteorol. Soc., 77, 437-471.

Kang, J., S. Yoon, Y. Shao, and S. Kim (2011), Comparison of vertical dust flux by implementing three dust emissions schemes in WRF/Chem, $J$. Geophys. Res., 116, D09202, doi:10.1029/2010JD014649.

Laurent, B., B. Marticorena, G. Bergametti, J. Léon, and N. Mahowald (2008), Modeling mineral dust emissions from the Sahara desert using new surface properties and soil database, J. Geophys. Res., 110(D18), D14218, doi:10.1029/2004JD005013.

Loosmore, G., and R. Cederwall (2004), Precipitation scavenging of atmospheric aerosols for emergency response applications: Testing an updated model with new real-time data, Atmos. Env., 38, 993-1003.

MacKinnon, D., G. Clow, R. Tigges, R. Reynolds, and P. Chavez (2004), Comparison of aerodynamically and model-derived roughness lengths (z0) over diverse surfaces, central Mojave Desert, California USA, Geomorphology, 63, 103-113.

Mahowald, N., C. Luo, and J. del Corral (2003), Interannual variability in atmospheric mineral aerosols from a 22-year model simulation and observational data , J. Geophys. Res., 108, 4352, doi:10.1029/2002JD002821.

Marticorena, B., and G. Bergametti (1995), Modeling the atmospheric dust cycle: 1 Design of a soil derived dust production scheme, J. Geophys. Res., 100, 16,415-16,430.
Marticorena, B., G. Bergametti, B. Aumont, Y. Callot, C. N'Doume, and M. Legrand (1997), Modeling the atmospheric dust cycle: 2 Simulations of Saharan dust sources, J. Geophys. Res., 102, 4387-4404

Menut, L. (2008), Sensitivity of hourly Saharan dust emissions to NCEP and ECMWF modelled wind speed, J. Geophys. Res. Atmos., 113 D16201, doi:10.1029/2007JD009522.

Menut, L., and B. Bessagnet (2010), Atmospheric composition forecasting in Europe, Ann. Geophys., 28, 61-74.

Menut, L., C. Schmechtig, and B. Marticorena (2005), Sensitivity of the sandblasting fluxes calculations to the soil size distribution accuracy, $J$. Atmos. Ocean. Tech., 22, 1875-1884.

Menut, L., G. Foret, and G. Bergametti (2007), Sensitivity of mineral dust concentrations to the model size distribution accuracy, J. Geophys. Res. Atmos., 112, D10210, doi:10.1029/2006JD007766.

Menut, L., O. Masson, and B. Bessagnet (2009), Contribution of Saharan dust on radionuclides aerosols activity levels in Europe? The 21-22 February 2004 case study, J. Geophys. Res. Atmos., 114, D16202, doi: 10.1029/2009JD011767.

Miller, R., et al. (2006), Mineral dust aerosols in the NASA Goddard Institute for Space Sciences ModelE atmospheric general circulation model, $J$. Geophys. Res., 111, D06208, doi:10.1029/2005JD005796.

Mlawer, E. J., S. Taubman, P. Brown, M. Iacono, and S. Clough (1997) Radiative transfer for inhomogeneous atmosphere: RRTM, a validated correlated k-model for the longwave, J. Geophys. Res., 102, $16,663-16,682$.

Morcrette, J., et al. (2009), Aerosol analysis and forecast in the European Centre for Medium-Range Weather Forecasts Integrated Forecas System: Forward modeling , J. Geophys. Res., 114, D06206, doi: 10.1029/2008JD011235.

Nickovic, S., G. Kallos, A. Papadopoulos, and O. Kakaliagou (2001), A model for prediction of desert dust cycle in the atmosphere, J. Geophys. Res., 106(D16), doi:10.1029/2000JD900794.

Perez, C., S. Nickovic, J. Baldasano, M. Sicard, F. Rocadenbosch, and V. E. Cachorro (2006), A long Saharan dust event over the Western Mediterranean: Lidar, sun photometer observations and regional dust modeling, J. Geophys. Res., 111, D15214, doi:10.1029/2005JD006579.

Pérez, C., et al. (2011), Atmospheric dust modeling from meso to global scales with the online nmmb/bsc-dust model: Part 1: Model description, annual simulations and evaluation, Atmos. Chem. Phys, 1124), 13,001-13,027, doi:10.5194/acp-11-13001-2011.

Prigent, C., I. Tegen, F. Aires, B. Marticorena, and M. Zribi (2005) Estimation of the aerodynamic roughness length in arid and semi-arid regions over the globe with the ERS scatterometer, J. Geophys. Res, 110, D09205, doi:10.1029/2004JD005370.

Prigent, C., C. Jimenez, and J. Catherinot (2012), Comparison of satellite microwave backscattering (ASCAT) and visible/near-infrared reflectances (PARASOL) for the estimation of aeolian aerodynamic roughness length in arid and semi-arid regions, Atmos. Meas. Tech., 5 , 2703-2712, doi:10.5194/amt-5-2703-2012.

Prospero, J., P. Ginoux, O. Torres, S. Nicholson, and T. Gill (2002), Environmental characterization of global sources of atmospheric soil dust identified with the NIMBUS 7 total ozone mapping spectrometer (TOMS) absorbing aerosol product, Rev. Geophys., 40, $1-31$.

Pryor, S., J. Schoof, and R. Barthelmie (2005), Empirical downscaling of wind speed probability distributions, J. Geophys. Res., 110, D19109, doi: 10.1029/2005JD005899.

Shao, Y., and I. Lu (2000), A simple expression for wind erosion threshold friction velocity, J. Geophys. Res., 105, 22,437-22,443.

Shao, Y., M. Raupach, and J. Leys (1996), A model for predicting aeolian sand drift and dust entrainment on scales from paddock to region, Austr. J. Soil Res., 34, 309-342.

Skamarock, W., J. Klemp, J. Dudhia, D. Gill, D. Barker, W. Wang, and J. Powers, (2007), A description of the advanced research wrf version 2 , NCAR Technical Note, pp. NCAR/TN-468+STR

Tegen, I., S. P. Harrison, K. Kohfeld, I. C. Prentice, M. Coe, and M. Heimann (2002), Impact of vegetation and preferential source areas on global dust aerosol: Results from a model study, J. Geophys. Res., 107(D21), AAC 14-1-AAC 14-27, doi:10.1029/2001JD000963.

Textor, C., et al. (2006), Analysis and quantification of the diversities of aerosol life cycles within AeroCom, Atmos. Chem. Phys., 6(7), 1777-1813, doi:10.5194/acp-6-1777-2006.

Textor, C., et al. (2007), The effect of harmonized emissions on aerosol properties in global models: An AeroCom experiment, Atmos. Chem Phys., 7(17), 4489-4501, doi:10.5194/acp-7-4489-2007.

Todd, M. C., et al. (2008), Quantifying uncertainty in estimates of mineral dust flux: An intercomparison of model performance over the Bodélé Depression, northern Chad, J. Geophys. Res., 113(D24), D24107, doi:10.1029/2008JD010476. 
Troen, I., and L. Mahrt (1986), A simple model of the atmospheric boundary layer: Sensitivity to surface evaporation, Bound.-Layer Meteorol., 37, 129-148.

Wang, K., Y. Zhnag, A. Nenes, and C. Fountoukis (2012), Implementation of dust emission and chemistry into the Community Multiscale Air Quality modeling system and initial application to an Asian dust storm episode, Atmos. Chem. Phys., 12, 10,209-10,237, doi:10.5194/acp-1210209-2012.

Wesely, M. L. (1989), Parameterization of surface resistances to gaseous dry deposition in regional-scale numerical models, Atmos. Environ., 23, 1293-1304.

Westphal, D. L., C. A. Curtis, M. Liu, and A. L. Walker (2009), Operational aerosol and dust storm forecasting, IOP Conference Series: Earth and Environmental Science, 7, 012007.

White, B. R. (1986), Encyclopedia of Fluid Mechanics, pp. 239-282, Gulf Publishing, Houston, TX, USA.
Zender, C. S., D. Newman, and O. Torres (2003), Spatial heterogeneity in aeolian erodibility: uniform, topographic, geomorphic, and hydrologic hypotheses, J. Geophys. Res., 108(D17), 4543, doi: 10.1029/2002JD003039.

Zhao, C., X. Liu, L. R. Leung, B. Johnson, S. A. McFarlane, W. I. Gustafson Jr., J. D. Fast, and R. Easter (2010), The spatial distribution of mineral dust and its shortwave radiative forcing over North Africa: Modeling sensitivities to dust emissions and aerosol size treatments, Atmos. Chem. Phys., 10(18), 8821-8838, doi:10.5194/acp-10-8821-2010.

Zilitinkevich, S. S., I. Mammarella, A. A. Baklanov, and S. M. Joffre (2008), The effect of stratification on the aerodynamic roughness length and displacement height, Bound.-Layer Meteorol., 129, 179-190.

Zobler, L., (1986), A world soil file for global climate modeling, NASA Tech. Memo. 87802 , p. 33 